\title{
THE HISTORY OF EARLY POLAR ICE CORES
}

Chester C. Langway, Jr.

January 2008

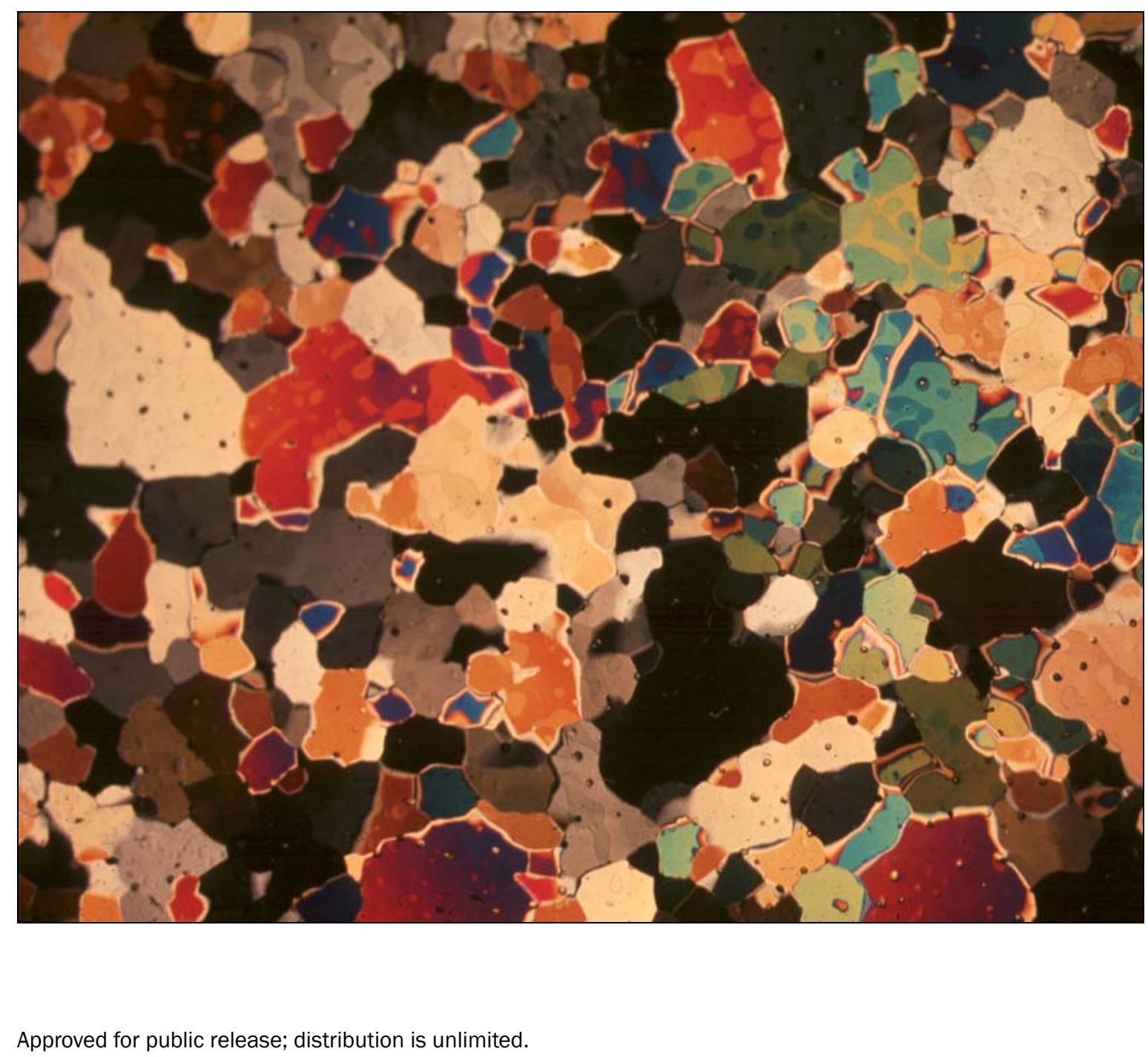


"Snowflakes fall to Earth and leave a message-."

Henri Bader (1907-1998)

Cover: Thin-section micrograph of a matrix of individual ice crystals from the 250-m depth (about 800 years old) from the Camp Milcent ice core. The different colors are due to the different orientations of the crystals. The larger crystals are about $1 \mathrm{~cm}$ in the elongated diameter. The small dark circles, better observed within the lighter crystals, are entrapped atmospheric air bubbles, incorporated and formed in the upper snow layers, originally as pore spaces. With time and increasing depth and overburden load pressure, they transform into individual air bubbles. Techniques of extracting the bubbles from ice core specimens, and analyzing the gases, provide chemical data on past changes in ancient atmospheric compositions.
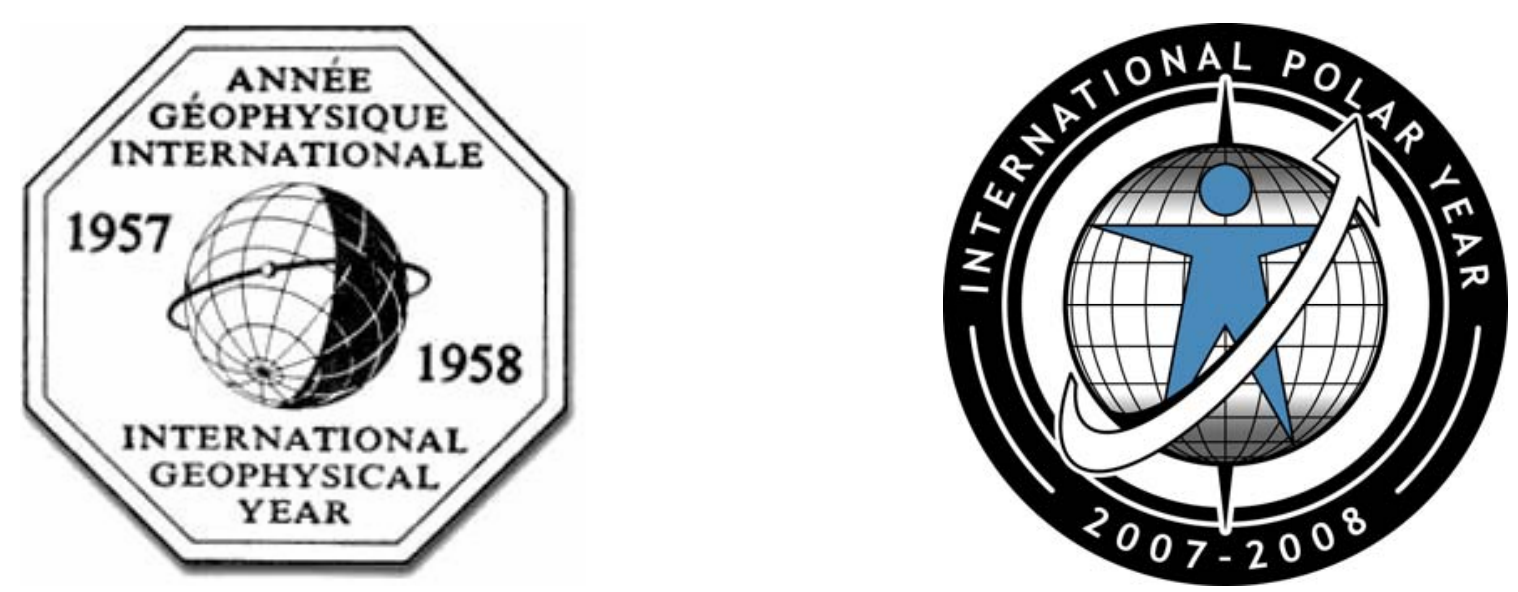

This report commemorates

the 50th anniversary of the Third International Polar Year (IGY) and the ongoing Fourth International Polar Year (IPY). 


\section{THE HISTORY OF EARLY POLAR ICE CORES}

Chester C. Langway, Jr.

USA SIPRE / USA CRREL / University at Buffalo

Approved for public release; distribution is unlimited. 


\begin{abstract}
The scientific knowledge of the Greenland and Antarctic ice sheets, and the subsequently derived Earth history, has been greatly increased during the past 50 years. Much of the new information was obtained from various studies made on a relatively small number of deep (300- $400 \mathrm{~m}$ ) and several very deep (some over $3000 \mathrm{~m}$ ) ice cores, recovered from the inland regions of both ice sheets by different national and international research teams. The beginning, development, and progress of deep polar ice core drillings and core studies is reviewed from the incipient pit study made by Ernst Sorge in 1930, through the trying efforts of three international core drilling projects mounted around 1950. The paper continues with a broad overview of the early role and achievements made by two related U.S. Army Corps of Engineers research laboratories: the Snow, Ice and Permafrost Research Establishment (SIPRE), and the Cold Regions Research and Engineering Laboratory (CRREL), from the early 1950s to the late 1980s. International partnerships of CRREL with the University of Copenhagen, Denmark, and the University of Bern, Switzerland, starting in 1962, established the foundation of polar ice core science.
\end{abstract}

DISCLAIMER: The contents of this report are not to be used for advertising, publication, or promotional purposes. Citation of trade names does not constitute an official endorsement or approval of the use of such commercial products. All product names and trademarks cited are the property of their respective owners. The findings of this report are not to be construed as an official Department of the Army position unless so designated by other authorized documents. 


\section{Contents}

Preface $\ldots \ldots \ldots \ldots \ldots \ldots$

Introduction ........................................................................................................................... 1

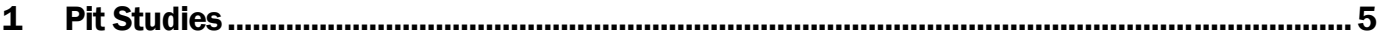

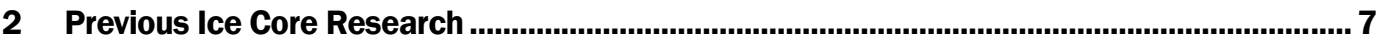

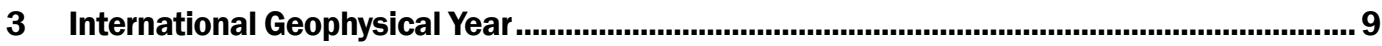

4 Post-IGY Bedrock Cores............................................................................................................... 17

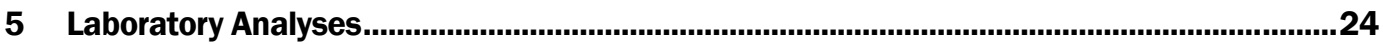

6 Greenland Ice Sheet Program...........................................................................................27

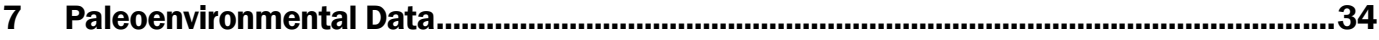

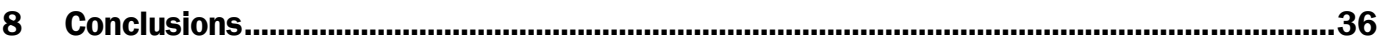

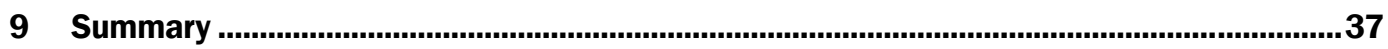

References............................................................................................................................................38

Appendix A: Recovered Deep and Very Deep Ice Cores ...............................................................47

Report Documentation Page..........................................................................................................48 


\section{Figures and Tables}

\section{Figures}

Figure 1. SIPRE Administration and Laboratory Building, Wilmette, IL, 1956 1

Figure 2. Henri Bader at Site 2 Greenland, 1954 ...................................................................... 2

Figure 3. Page from Corps of Engineers, 1st Engineers Arctic Task Force's project support document for SIPRE in northwest Greenland, summer 1957

Figure 4. Index maps of main core drilling sites for SIPRE/CRREL/GISP in Greenland and Antarctica, and some coastline support stations

Figure 5. Meeting of the Technical Panel on Glaciology in Washington, DC, pre-IGY, ca 1955 ....... 10

Figure 6. Field camp at Site 2, 1956-1957 ............................................................................. 10

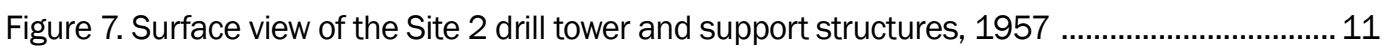

Figure 8. Below-surface core drilling trench with crew at the rig's borehole, 1957 ........................ 12

Figure 9. R. Lange, project leader, and J. Tedrow, chief driller, with crew assistants at the drill hole, 1957

Figure 10. Briefing in the field for SIPRE science research chiefs at end of site 2 drilling, September 1957

Figure 11. Bubble pressure measurements in the Jamesway field laboratory used to study changing stress relaxation in ice core samples

Figure 12. Plotted results of stable oxygen isotope ratio measurements on a continuous ice core interval from $300 \mathrm{~m}$ deep for the Site 2 core

Figure 13. Schematic diagram illustrating the approach and procedures used to investigate the Site 21957 ice core

Figure 14. Plan view of the sub-ice configuration of the Camp Century facility 18

Figure 15. Surface view of the ramp entering below surface Camp Century complex, 1964 ......... 19

Figure 16. Main 400-m-long access trench below the surface at Camp Century, 1964 ................. 19

Figure 17. Thermal coring rig in Trench 12 at Camp Century, 1964 .............................................2 20

Figure 18. Cross section of Camp Century's water well, 1963 ........................................................2 22

Figure 19. E.F. Fireman, Smithsonian Astrophysical Observatory, at a trench-level waterwell breakout station and a micro-filtering system, 1963 ..............................................................2

Figure 20. One of the ice core storage freezer compartments at CRREL, 1965 ............................. 24

Figure 21. Camp Milcent, 1973 ..............................................................................................29

Figure 22. Loading ski-equipped C-130 aircraft with ice cores recovered at Camp Milcent,

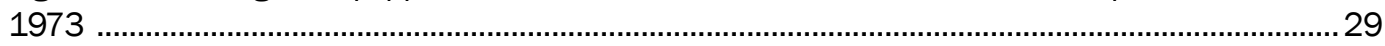

Figure 23. Camp Crete, 1974 ................................................................................................. 30

Figure 24. B.L. Hansen at the thermal drilling rig at Camp Crete, 1974 .......................................30

Figure 25. Dye 3, Greenland radar and communications site, 1980 ............................................ 31

Figure 26. Dansgaard, Langway, and Oeschger in the science trench at Dye 3 shortly after bottom ice was reached at $2037 \mathrm{~m}$ on August 15, 1981 


\section{Table}

Table 1. Early pit studies and ice core drilling projects ................................................................. 5 


\section{Preface}

This report was prepared by Dr. Chester C. Langway, J r., a former researcher at the Snow, Ice and Permafrost Research Establishment (SIPRE), Wilmette, IL, and the Cold Regions Research and Engineering Laboratory (CRREL), Hanover, NH, (1956- 1975) and a former faculty member at the University at Buffalo (State University of New York) (19751994). During his years at SIPRE and CRREL, he participated in and was responsible for developing the SIPRE/ CRREL field and laboratory ice core research program, the core sample storage responsibilities, and the scientific redistribution of ice core samples for external studies. During his last nine years at CRREL he also served as Chief, Snow and Ice Research Branch. He is now retired.

The renewed pursuit to recover deep ice cores began and succeeded during the IGY, under the visionary foresight of Henri Bader and the engineering inventiveness of B. Lyle Hansen, and in doing so, introduced a new and still emerging field of polar ice core science. A.P. Crary, distinguished polar researcher and Chief Scientist of National Science Foundation's Division of Polar Programs during the difficult early days of this research, was a lasting pillar of dedicated support. Full recognition and complete appreciation is extended to a long list of the U.S. Army's Corps of Engineers Director's of the SIPRE and CRREL laboratories, namely COL W.H. Parsons, J r., COL W.L. Nungesser, COL P.G. Krueger, COL D.A. Kellogg, COLJ .E. Wagner, COLJ J.F. Castro, and COL R.L. Crosby. All concurred with the unique and genuine mutual agreement to support and enable the complete ice core research program to be conducted at the laboratories, in cooperation with and in support of the U.S. NSF.

During the nearly forty years of history compressed into this paper on early ice cores, many valuable contributions were made by a great number of individuals, notably W. Dansgaard and H. Oeschger and their laboratories; they stand tall in this category. Many others to be thanked are noted or referenced in the text. The important and necessary close interaction, advice, and support of numerous key personnel from NSF's Office and Division of Polar Programs is gratefully acknowledged and sincerely appreciated; these include T.O. J ones, A.P. Crary, P.M. Smith, L.O. Quam, G. Llano, P. Lewis, K. Moulton J . Huffman, G. Guthridge, M.D. Turner, 
J . Fletcher, E.P. Todd, R.H. Rutford, D.A. Anderson, R.L. Cameron, J . Zwally, H. Borns, E. Chang, and many, many others, especially J.H. Zumberge (NAS/ CPR, Univ. So. Cal., Univ. Mich.), L.M. Gould (Chm., NAS/CPR), E.D. Goldberg, (UC San Diego), L. DeGoes (NRC), G. Nancollas (Univ. at Buffalo), and C. Wroe Wolf (Boston Univ.). Sadly, because of the time span covered in this reporting, a number of the above have passed on, but their contributions are real, mostly registered in the literature, and remain fixed in the memory of those who labored with them.

Special units of the U.S. Army, U.S. Air Force, USAF Air National Guard, and the U.S. Navy provided abundant transportation, logistical, and operational support for fieldwork in Greenland and Antarctica. The author fully acknowledges and enthusiastically thanks them for their professional skills and tireless efforts in making the field research projects safe and successful; they know their job and did it well.

The author is further indebted to several colleagues who reviewed draft copies of this report; many were field or laboratory participants or took an active part in different aspects of the research discussed herein; they include J. Weertman, R, Rutford, G. Denton, H. Ueda, J. Brown, G. Frankenstein, B. Stauffer, H. Clausen, G.J . Wasserburg, and J . Splettstoesser. All are experienced and seasoned polar regions research investigators who were generous with their time and perceptive in their scrutiny. M.R. Albert and D.W. Cate provided exceptional editorial and computer guidance.

The report was prepared under the general supervision of Dr. Robert E. Davis, Director, CRREL.

The Commander and Executive Director of ERDC is COL Richard B. J enkins. The Director is Dr. J ames R. Houston. 


\section{Introduction}

Modern ice core drilling technology and the following ice core science studies were initiated by the U.S. Army Corps of Engineers in the early 1950s, just before the International Geophysical Year (IGY) program began, under the formulation and leadership of Henri Bader, Chief Scientist of the U.S. Army Snow, Ice and Permafrost Research Establishment (SIPRE), in association with his research Branch Chiefs, B. Lyle Hansen, J ames A. Bender, W. Keith Boyd, Robert W. Gerdel, and William H. Parrott, and others. During 1956-1959, the full span of the IGY's field work, SIPRE (Fig. 1) successfully recovered the first deep ice cores ever obtained, and suitable for integrated scientific study, from both the inland regions of the Greenland and Antarctic ice sheets. In 1961, SIPRE united with the U.S. Army Arctic Construction and Frost Effects Laboratory (ACFEL) to form one laboratory, the U.S. Army Cold Regions Research and Engineering Laboratory (CRREL), and Bader (Fig. 2) retired and joined the faculty at the University of Miami, FL. CRREL continued with the ice core research base established by SIPRE and, in 1966 and 1968, succeeded in obtaining the first very deep ice cores that penetrated the entire vertical dimension of the inland regions of both the Greenland and Antarctic ice sheets.

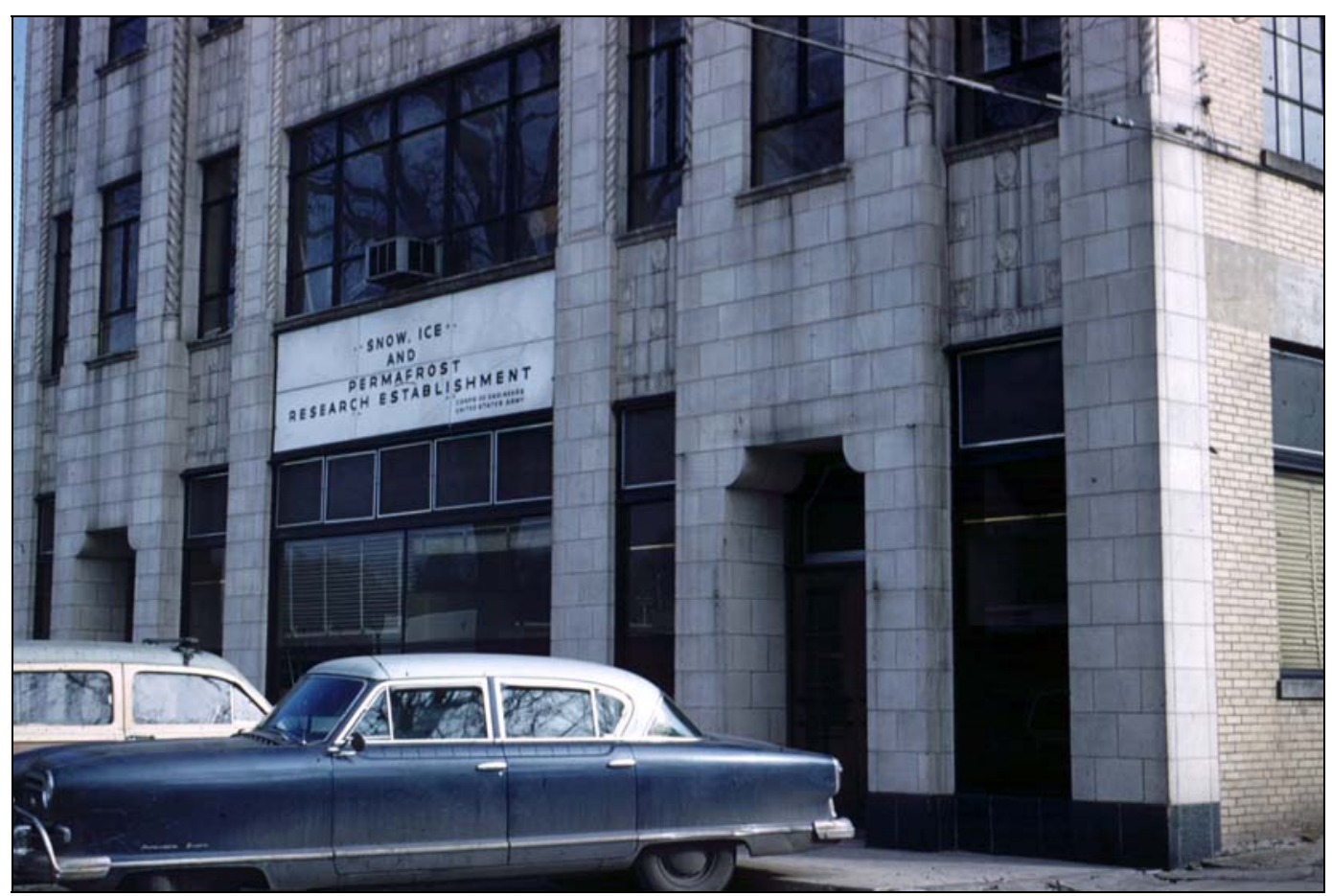

Figure 1. SIPRE Administration and Laboratory Building, Wilmette, IL, 1956. 


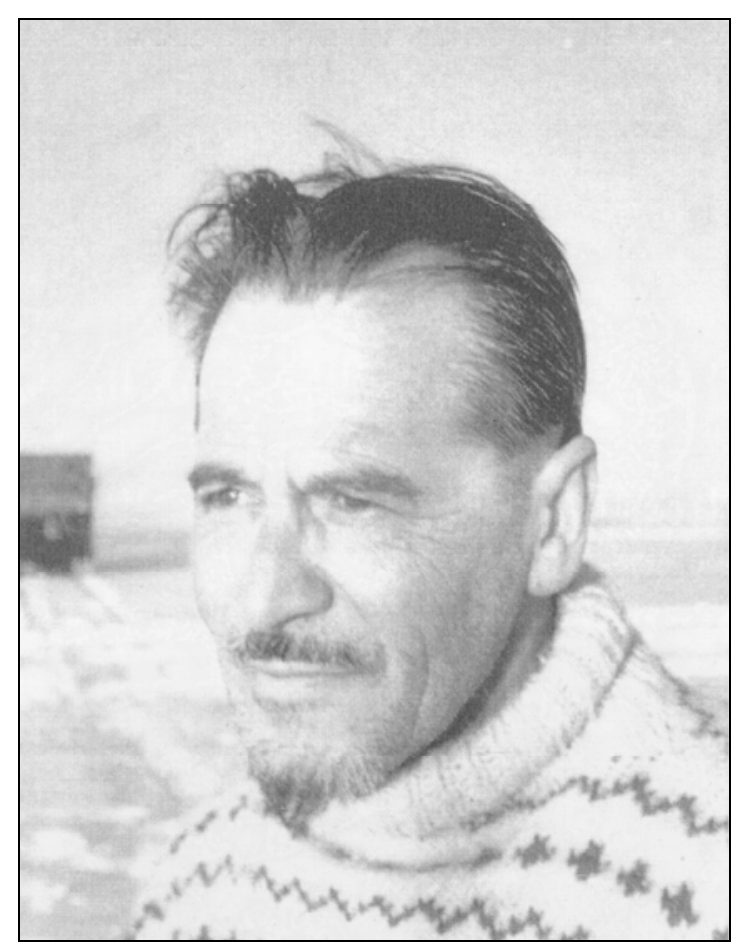

Figure 2. Henri Bader at Site 2 Greenland, 1954. (From the Bader collection, University of Miami.)

Together, SIPRE and CRREL amassed nearly forty years of research experience and achievements in deep polar ice core drillings and core analyses on a large scale, and they established the fundamental drilling technology for retrieving deep ice cores for climatologic archives. At the beginning, and for more than a decade, SIPRE/ CRREL was solely responsible for establishing, defining, and developing the entire U.S. ice core drilling research program. In addition, the U.S. Army Corps of Engi-

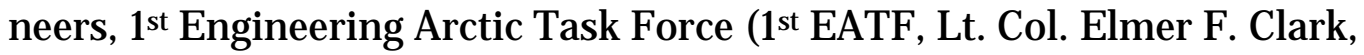
Commanding Officer; Capt. Ray S. Hansen, Executive Officer), provided the complete field support required for SIPRE's research on inland Greenland during the pre-IGY, in 1956 and 1957 (Fig. 3). This included all aspects of logistics, air and surface transportation, communications, field camp construction, and living accommodations. The U.S. Navy Air Development Squadron (VX-E 6) and the Navy's Seabee support component performed similar logistical services in Antarctica during the 19571959 IGY period. The construction of Camp Century, Greenland, an experimental nuclear-powered, beneath-the-snow-surface, year-round, 200-person living facility, was completed in 1959 by the Corps of Engineers, Polar Research and Development Center (PRDC), Col. Robert J . Giesen, Commanding Officer. The Corps also fully supported CRREL in its first, post-IGY bedrock-drilling project at Camp Century, Greenland, from 


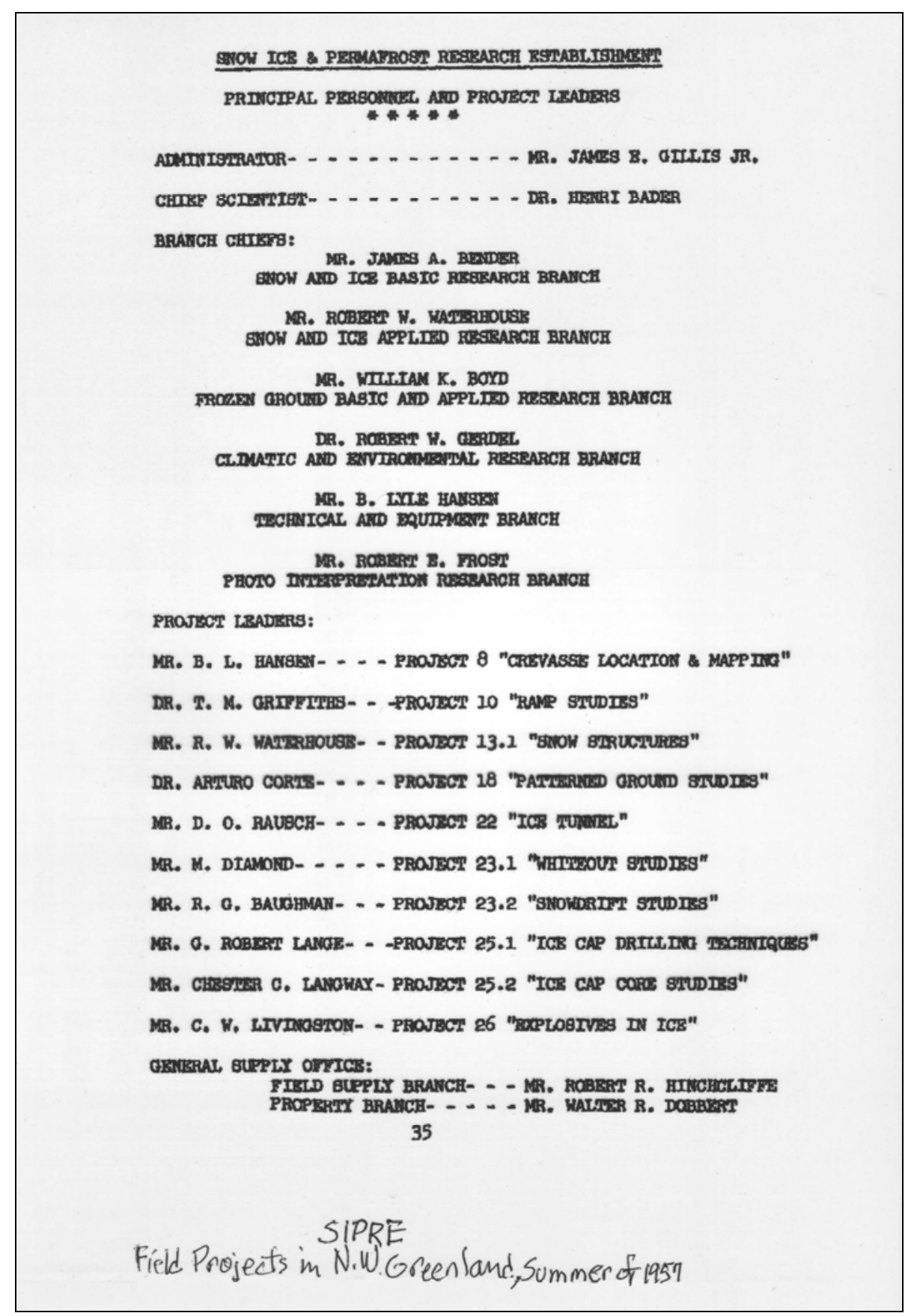

Figure 3. Page from Corps of Engineers, 1st Engineers Arctic Task Force's project support document for SIPRE in northwest Greenland, summer 1957.

1960 to 1966 (Fig. 4). Thereafter, the U.S. Navy fully supported CRREL again at Byrd Station, Antarctica, in its first to bedrock-drilling project there from 1966 to 1968.

During the mid-1960s, CRREL entered into strong international laboratory and field research collaborations with the University of Copenhagen, 


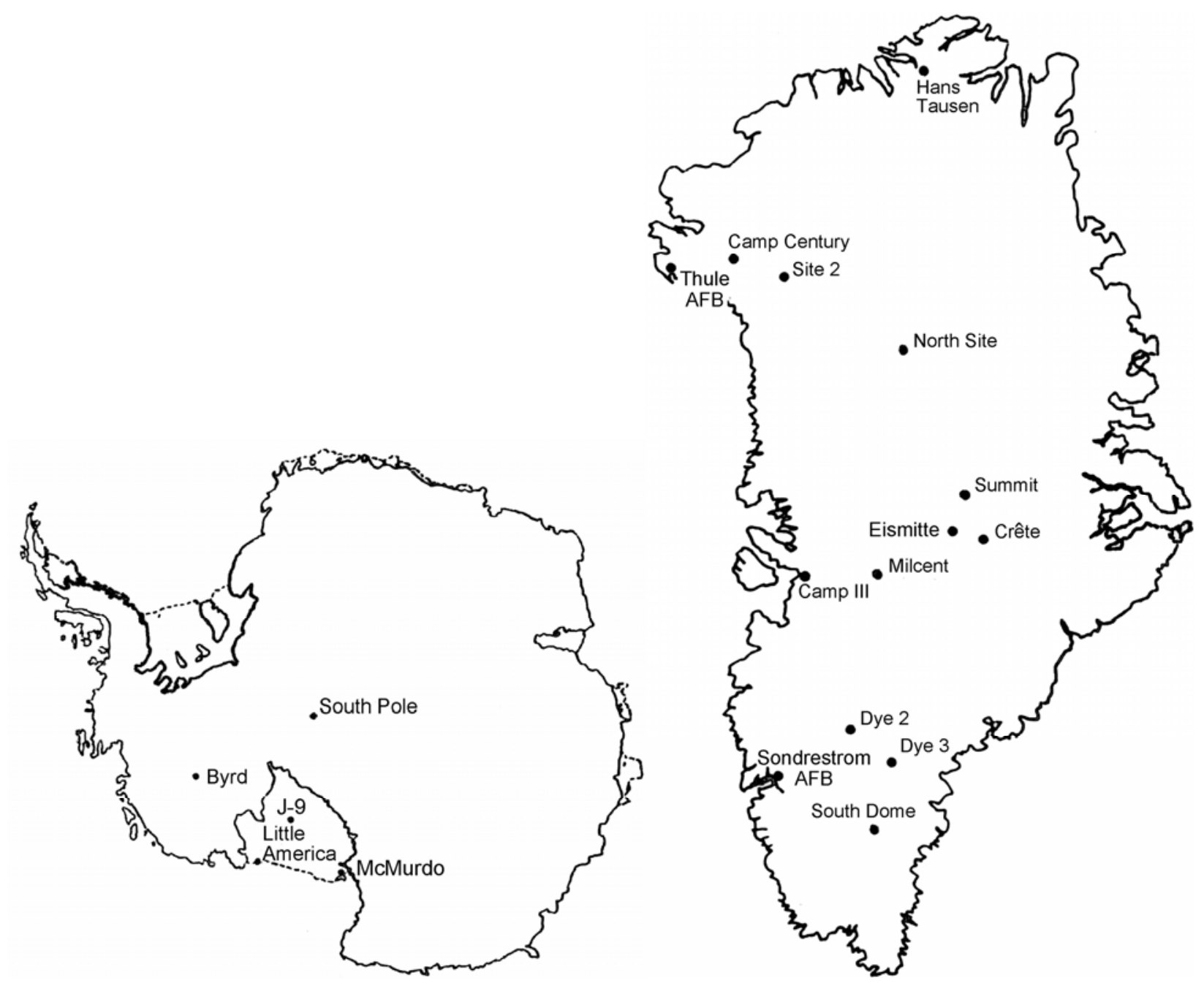

Figure 4. Index maps of main core drilling sites for SIPRE/CRREL/GISP in Greenland and Antarctica, and some coastline support stations. (The two maps are drawn at different scales.)

Denmark, and the University of Bern, Switzerland, as well as with other U.S. and foreign universities and institutes. The author participated in and was responsible for developing the SIPRE/CRREL field and laboratory ice core research program, the core sample storage responsibilities, and the scientific redistribution of ice core samples for external studies from 1957 to 1975 (Langway 1958a, Langway and Hansen 1970). In 1975, Langway accepted a faculty position and Chairmanship of the Department of Geology at the University at Buffalo (State University of New York), where he continued his active ice core research activities, and with the agreement of CRREL and the authorization of the NSF, he accepted the responsibility for the curatorship of all deep ice cores recovered by the U.S. deep core drilling program at the University at Buffalo for the next 17years. 


\section{Pit Studies}

The original inspiration to probe into the deep interior of ice sheets began to evolve in Greenland and Spitzbergen in the early 1930s (Table 1) with the original studies by Ahlman (1933, 1935) and Sverdrup (1935), and especially following the path-breaking research made by Ernst Sorge $(1933,1935)$ during the Alfred Wegener Expedition to central Greenland in 1930-1931 (Schwarzbach 1986). Sorge was the first to systematically and quantitatively study the near-surface snow/ firn strata in a 15-m-deep pit at Station Eismitte. He hand-dug the pit adjacent to his beneath-the-surface snow cave, which served as his living quarters during his seven-monthlong wintering-over stint. After meticulous examination of the structural features and careful measurement of continuous density and other physical properties over the pit profile, Sorge determined the characteristics of the individual limits of annual snow accumulation (Sorge 1935). This research validated the feasibility of measuring the preserved annual snow accumulation cycles (Bader 1958), like measuring frozen precipitation in a rain gauge, at least for the upper surface layers. Bader later transformed Sorge's data into a mathematical expression (Sorge's Law of Densification)

Table 1. Early pit studies and ice core drilling projects.

\begin{tabular}{|l|l|}
\hline \multicolumn{1}{|c|}{ Years } & \multicolumn{1}{c|}{ Accomplishment } \\
\hline Early Glacier Studies & \multicolumn{1}{|c|}{ Thickness boring in Swiss glaciers } \\
\hline$\sim 1842$ & Surface traverses on Arctic glaciers \\
\hline$\sim 1885-1930$ & $\begin{array}{l}\text { Ahlman (1933, 1935) and Sverdrup (1935). Greenland and } \\
\text { Spitzbergen. Established beginning of systematic glacier } \\
\text { measurements. }\end{array}$ \\
\hline 1930-1933 & $\begin{array}{l}\text { Sorge at Station Eismitte, Greenland. Developed concept of } \\
\text { seasonal deposits using density, ice layers, and depth hoar } \\
\text { measures. }\end{array}$ \\
\hline 1930-1933 & $\begin{array}{l}\text { British-Norwegian-Swedish Antarctic Expedition. Droning Maud } \\
\text { Land, coastal shelf ice } 100 \text { m. Grain size, density, crystal } \\
\text { orientation, and air bubbles measured (Schytt 1958) }\end{array}$ \\
\hline 1949-1952 & $\begin{array}{l}\text { Juneau Ice Field Research Project (Miller 1954). } \\
\text { Taku Glacier, Alaska 100 m. }\end{array}$ \\
\hline 1949-1950 & $\begin{array}{l}\text { Expeditions Polaires Francaise (Heuberger 1954). South Greenland } \\
\text { inland ice sheet. 126-150 m. }\end{array}$ \\
\hline 1950-1951
\end{tabular}


(Bader 1953) and used it in 1953 in northwest Greenland to interpret the annual strata in his own 37-m-deep pit, which he extended to $47 \mathrm{~m}$ by using a "SIPRE" hand-coring auger (Bader et al. 1955). Unlike Sorge, who had to depend on his own exhaustive individual manual labor over a seven-month period, Bader recruited volunteer field hands from the U.S. Army to excavate his pit, in short order, using chain saws.

Between 1952 and 1955, Carl Benson, with Richard Ragle and others from SIPRE, made a systematic and comprehensive study of the distribution of the regional, near-surface snow accumulation over major portions of nearly the entire surface of the Greenland ice sheet using a tracked vehicle (Weasel) for transportation. Benson relied on U.S. Air Force C-46 and C54 aircraft from Thule Air Base for resupply airdrops for fuel and other camp provisions. Along the trail he hand-excavated several scores of pits at prescribed locations (Benson 1959). This Herculean research effort resulted in a valued, detailed regional mass-balance study over a large portion of the inland Greenland ice sheet. In some pits (about $4 \mathrm{~m}$ deep), Benson collected widely spaced snow/ firn samples from the pit walls for oxygen isotope analyses by Samuel Epstein at the California Institute of Technology. In spite of the non-continuous, wide spacing of the samples, the oxygen isotope data produced from the upper snow/ firn layers of some pit walls were highly suggestive of seasonal snowfall relationships (Benson 1962, p. 42-43). This research formed the basis for using oxygen isotope ratio measurements in a continuous mode, in the late 1950s, to reliably determine annual accumulation cycles (over continuous 1.5- to 4-m intervals, at four 100-m-spaced depths) in the 411-m-deep SIPRE Site-2 ice core (Langway 1962, p. 108-110; 1967, p. 32-43). Oxygen isotope analysis has been used as a standard, critically important method of analysis for ice cores since then. 


\section{Previous Ice Core Research}

It was nearly twenty years after Eismitte before the seeds of interest planted by Sorge's important research results were seriously acted upon (Table 1). The next step in the saga began, around 1950, almost simultaneously by three separate international research teams, mounted at three distant global locations, using three different mechanical ice core drilling rigs. One was during 1949-1952 by members of the Norwegian- BritishSwedish Antarctic Expedition (NBSAE) (Swithinbank 1957). They cored to nearly $100 \mathrm{~m}$ on the polar ice shelf along the Queen Maud Land Coast, Antarctica (Schytt 1958). Another was during 1949-1950 by members of the J uneau Ice Field Research Project (J IRP). Here, Bader cored to about 100 m into the temperate Taku Glacier in Alaska (Miller 1954). The other was during 1950-1951 by members of Expeditions Polaires Francaises (EPF). They reported boring two holes to depths of 126 and $150 \mathrm{~m}$ on the central Greenland inland ice at Camp VI and Station Central (Heuberger 1954). All three projects reported exhaustive efforts and marginal success in terms of anticipated depth reached and quality of ice core recovered. The poor physical condition and large gaps in the core profiles precluded stratigraphic analyses, although some interesting physical property studies were made on fragments or sections of the Alaskan core by Bader and his student assistant, Gerald Wasserburg (Miller 1954), and on the Antarctic core by Valter Schytt (1958).

In the late 1940s Henri Bader, a Swiss-born U.S. citizen and internationally recognized authority on snow and ice physics (Bader et al. 1939), was a research professor of mineralogy at Rutgers University, NewJ ersey, with prior research experience in ice core drilling in Alaska. Soon thereafter, he was appointed by a U.S. government research panel to conduct a survey of the existing state of the art of polar latitude research in Europe and report his findings (Korsmo 2007a). Bader's analysis was one of the main factors in convincing the panel to recommend establishing a government laboratory to investigate the topic, which was implemented under the civil works engineering research mission of the U.S. Army Corps of Engineers, in 1949, as the Snow, Ice, and Permafrost Research Establishment.

With the scientific skills of Bader and his inventive Chief of Technical Services, B. Lyle Hansen, and others, SIPRE further developed the hand-oper- 
ated "SIPRE auger" to penetrate to shallow depths of about $50 \mathrm{~m}$, as well as other mechanical shallow-depth ice-coring augers (Mellor 1964, Mellor and Sellmann 1976, Rand and Mellor 1985). These projects represented some of the first engineering research tasks undertaken at the new laboratory. SIPRE also developed a unique snow/ice-property field-study kit for international use, as a U.S. contribution to the entire international IGY glaciological research effort, to help standardize the physical measurements of near-surface snow/ ice deposits on the ice sheets (Bader 1958). In August 1956, Bader, with the assistance of Project Leader Richard Ragle, William Marshall, J ack Tangerman, Chester Langway, and others from SIPRE, conducted a pre-IGY "Polar Glaciology Study Course," on the edge of the Greenland Ice Sheet to acquaint 17 international researchers with the snow-study kits before their departure for Antarctic research projects the following field season (Ragle 1958). This collective engineering and scientific research activity and Bader's pioneering ice core drilling experience in Alaska turned out to be fortuitous and greatly contributed to the later interests and successes in the development of the deep ice core drilling systems at SIPRE/ CRREL. 


\section{International Geophysical Year}

The early 1950s was a time of renewed and stimulated interest in international polar latitude research, marked by the Third International Polar Year activities (IPY) in 1957-1958; the program was soon renamed the International Geophysical Year (Bader 1958, Crary et al. 1962, Korsmo 2007b). At long last, the neglected and long overdue research areas in the high latitudes, in some of the most distant, desolate and inhospitable regions on Earth, would be targeted and sponsored by every nation choosing to participate. The IGY Antarctic glaciology research program involved the efforts of 12 nations, with 48 stations on the continent. The Arctic glaciology research program involved 14 nations, with 302 stations north of the 60th parallel. Scientific investigations were made in 14 disciplines (Gould 1970). The U.S. was a major contributor in the pre-planning stages and in the communications, logistics, and transportation phases, with the extensive involvement and support of the U.S. Navy, during the entire IGY field operations. The U.S. also participated by conducting its own broadbased interdisciplinary research effort.

One of the high-priority, long-term research projects evaluated and recommended by the U.S. National Academy of Sciences (NAS)/ National Committee for the IGY (Lawrence M. Gould, Chair) was to deep core drill into polar ice sheets for scientific purposes. In committee (Fig. 5), this project's concept was convincingly argued by Bader, to be revisited and tested again. He maintained that if the research succeeded, it would be a major contribution by the U.S. to the IGY objectives, and it would significantly advance polar science (Bader 1962). The committee adopted his recommendation, and subsequently the U.S. National Science Foundation (NSF) tasked SIPRE with the responsibility for defining, developing, and conducting the entire U.S. ice core drilling and ice core studies research program (including all sites labeled as IGY and GISP locations in Appendix A), under a joint interagency agreement.

The SIPRE pre-IGY pilot drilling trials were successfully conducted at Site2, northwest Greenland (Fig. 6) in 1956 (305 m) and 1957 (411 m) by Project Leader Robert Lange, Chief Driller J ack Tedrow (Lange 1973), and a group of Dartmouth College student assistants and military support assistants. A commercially modified, mechanical-rotary Failing-1500 rock- 


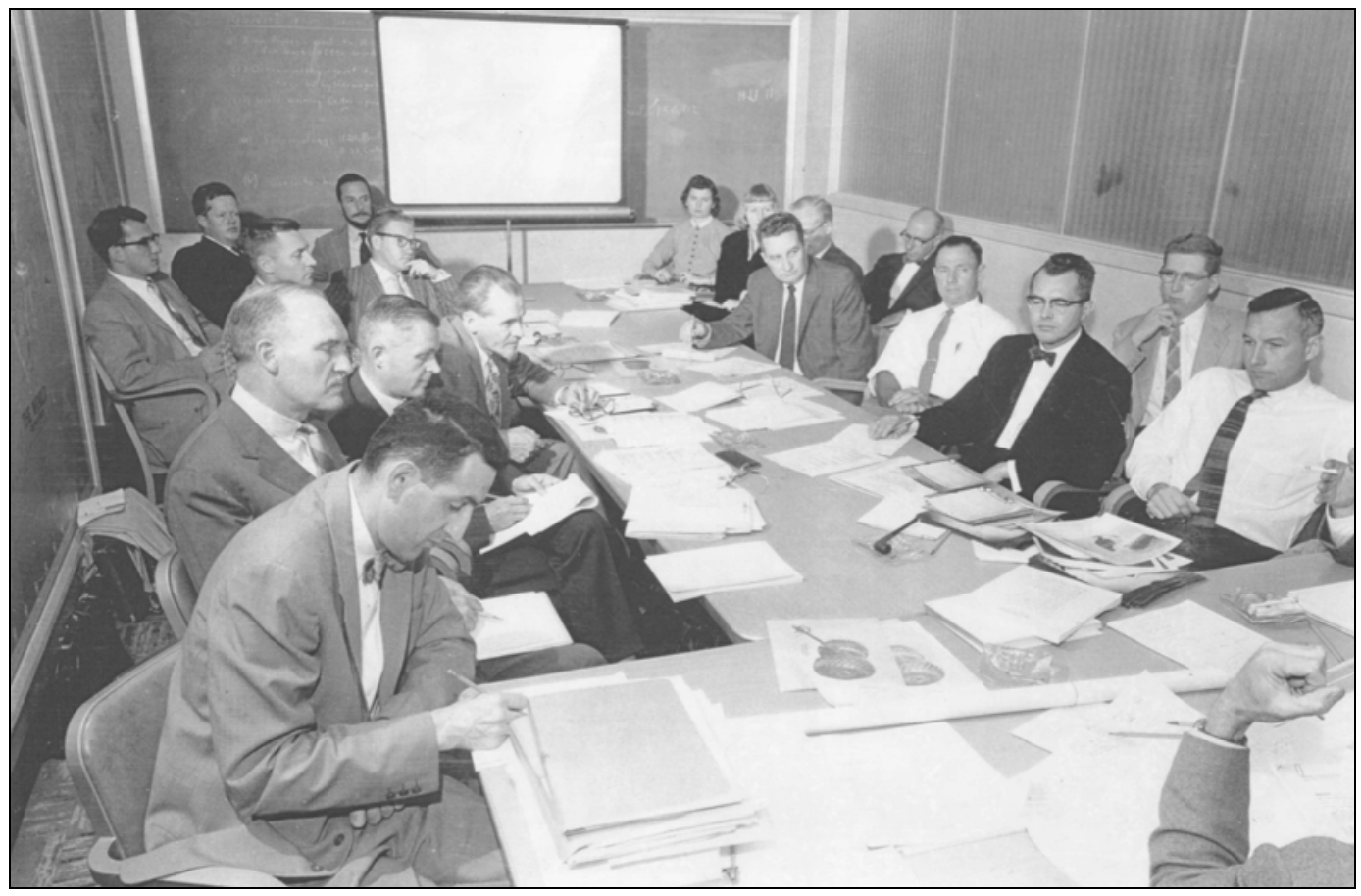

Figure 5. Meeting of the Technical Panel on Glaciology in Washington, DC, pre-IGY, ca 1955. Left side front row: John Hanessian, staff officer, TPG; Richard Foster Flint, Yale University; Richard Goldthwaite, Ohio State University; Henri Bader, SIPRE; Ned Ostenso, Office of Naval Research; last man, unknown; second row left: George Rigsby, SIPRE/California Institute of Technology; David Nutt, Dartmouth College; Third row left: unknown. Right side front row: the left arm of Lawrence Gould, chairman of committee; James Zumberge, University of Michigan; Troy Pêwe, University of Alaska; Robert Sharp, California Institute of Technology; Lou Quam; remaining five individuals unknown. (Photo from H. Bader, ca 1990.)

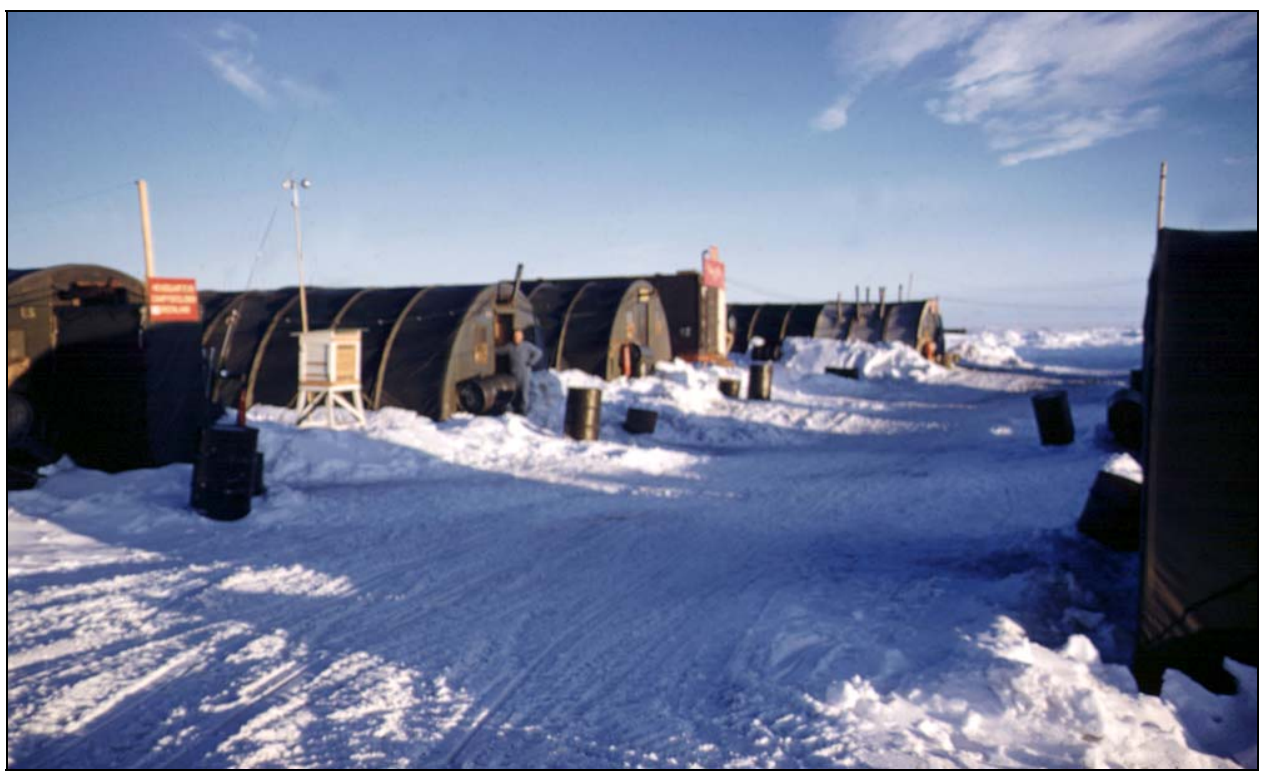

Figure 6. Field camp at Site 2, 1956-1957. The insulated canvas "Jamesway" shelters served as living, eating, and working spaces and were heated by kerosenefed pot-belly stoves. 


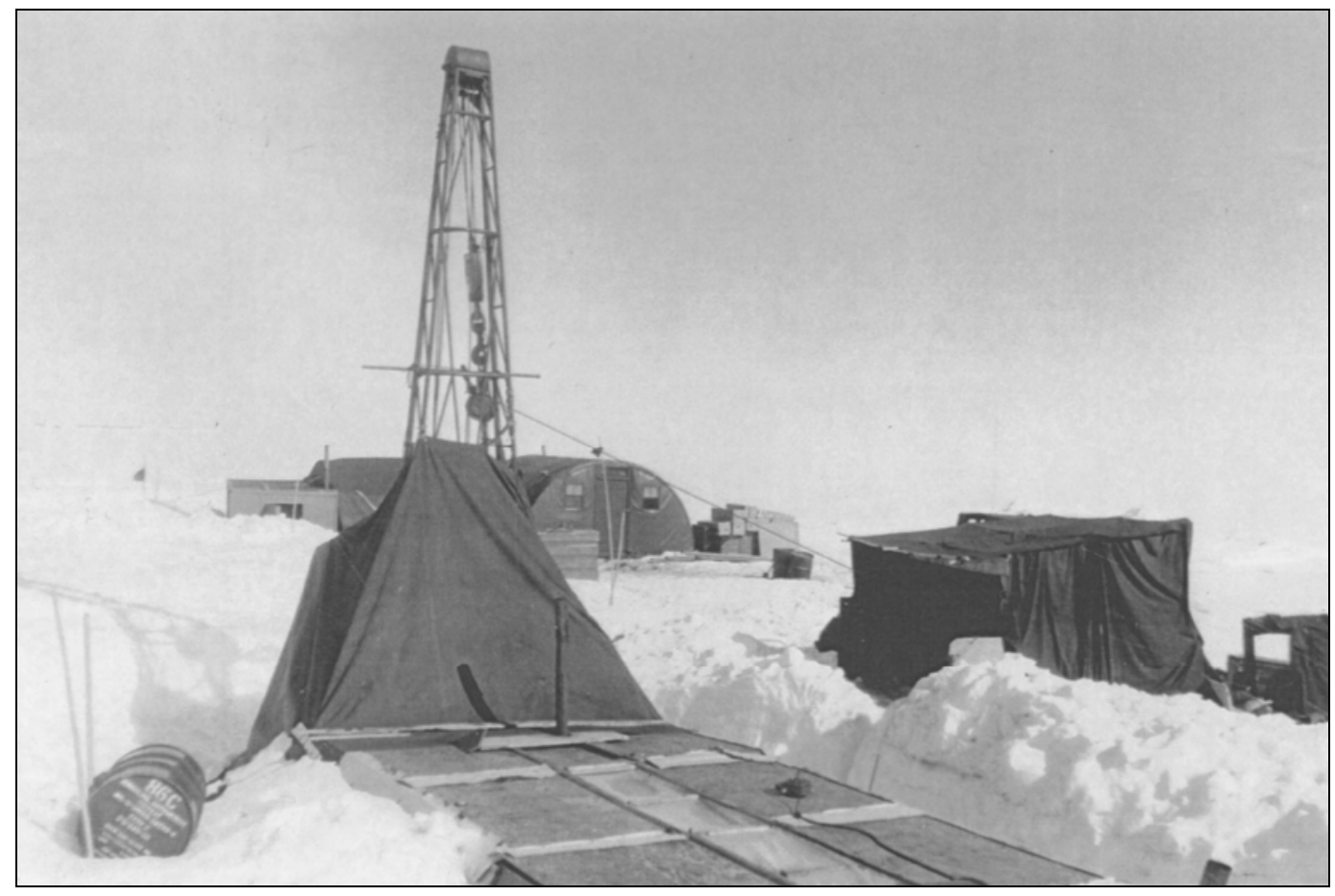

Figure 7. Surface view of the Site 2 drill tower and support structures, 1957. The Jamesway shelter in the background served as a heated office and warm laboratory at the drill site.

coring rig was used (Fig. 7, 8, 9), fitted with special ice cutting bits. Ice chips were collected in a trap in the core recovery barrel, and a unique, cooled-compressed-air system used as a medium for removing the ice chips. Although functionally successful, the modified rock-drilling rig had a time-consuming cumbersome drawback: the heavy, 20-ft- long, endthreaded stainless steel drill pipes used for the drill string had to be connected and disconnected for each core run, up and down; with increasing depth this proved to be very inefficient. The problem was solved for following rigs by replacing the pipe string with a wire-line system.

Project Leader William Marshall and Langway were responsible for processing and recording the 10-cm-diameter cores at Site 2 during the summer of 1956. Analysis of the 1957 ice core became the responsibility of Langway (Fig. 10) (1958a) assisted by student Timothy Foul (MIT) and Specialists Edward Swartz and Brent Hamil (1st EATF). With the drilling experience gained previously, the 1957 core was recovered in much better physical condition, much more continuous, and deeper than the 1956 core; hence it was selected for detailed laboratory investigations on this firstever, nearly continuous, vertical exposure of an active polar ice sheet. A simple field laboratory was set up in a heated "J amesway" shelter on the surface (Fig. 7, center background) during the field recovery of the 1957 


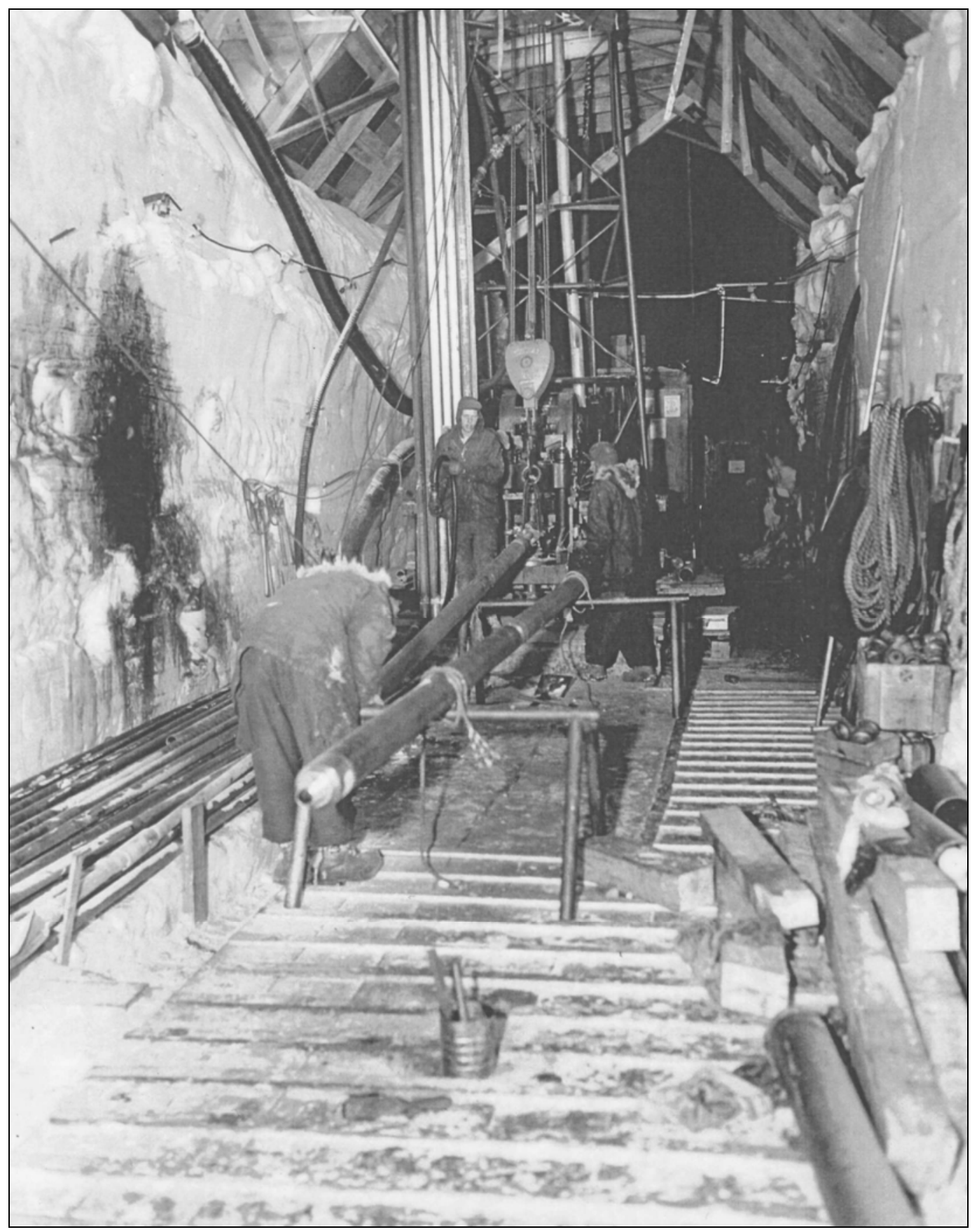

Figure 8. Below-surface core drilling trench with crew at the rig's borehole, 1957.

core. A time study was started to measure the stress-relaxation of core specimens as a function of depth, and the increasing hydrostatic load pressures that existed at their depths of recovery, by making precise density measurements (accuracy to $\pm 15 \times 10^{-5} \mathrm{~g} / \mathrm{cm}^{3}$ ) in the $-12^{\circ} \mathrm{C}$ trench lab. After the specimen was melted in a vacuum system under a liquid, the volume of atmospheric air released was measured in a burette (Fig. 11). 


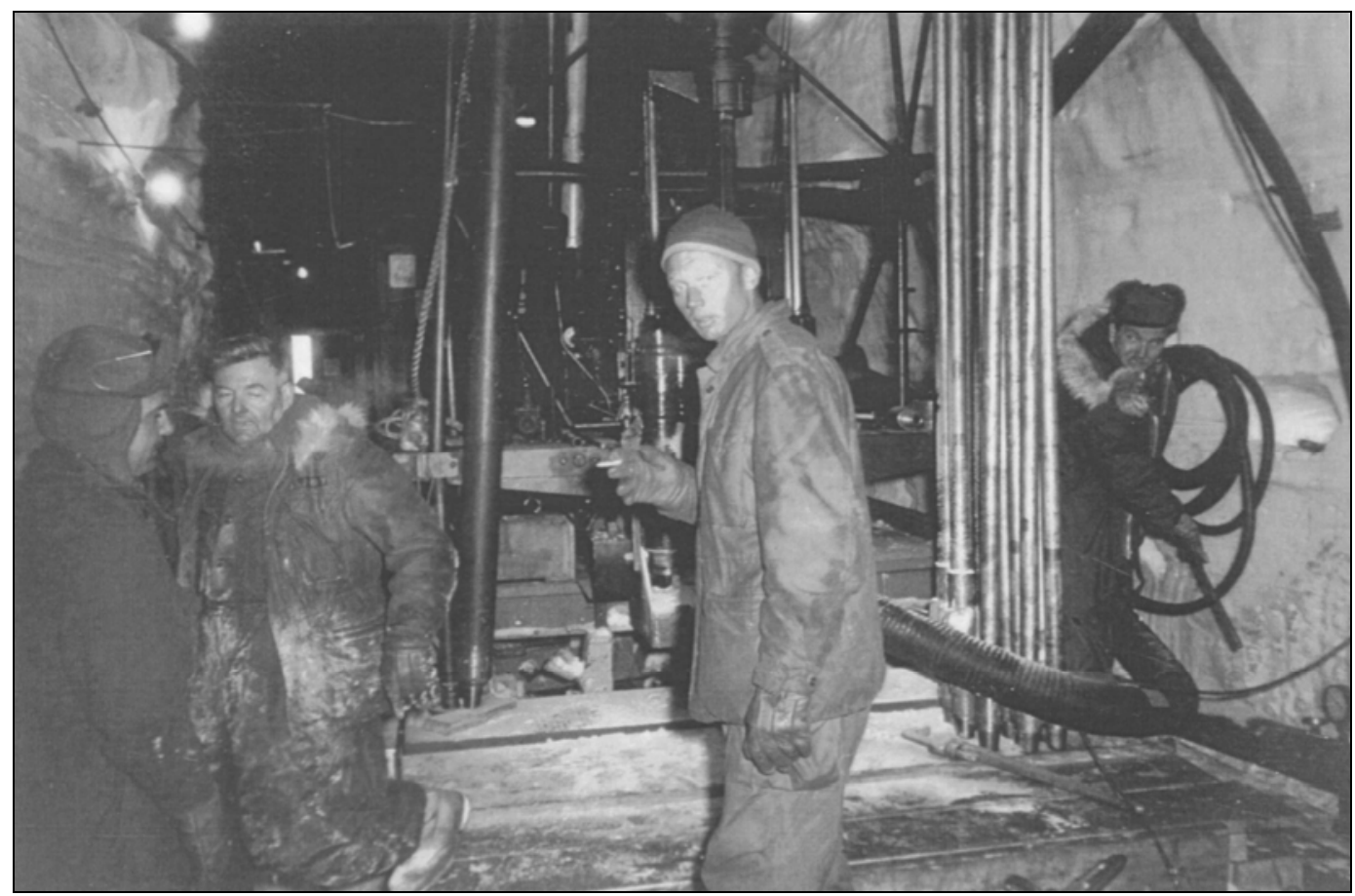

Figure 9. R. Lange, project leader, center, and J. Tedrow, left, chief driller, with crew assistants at the drill hole, 1957.

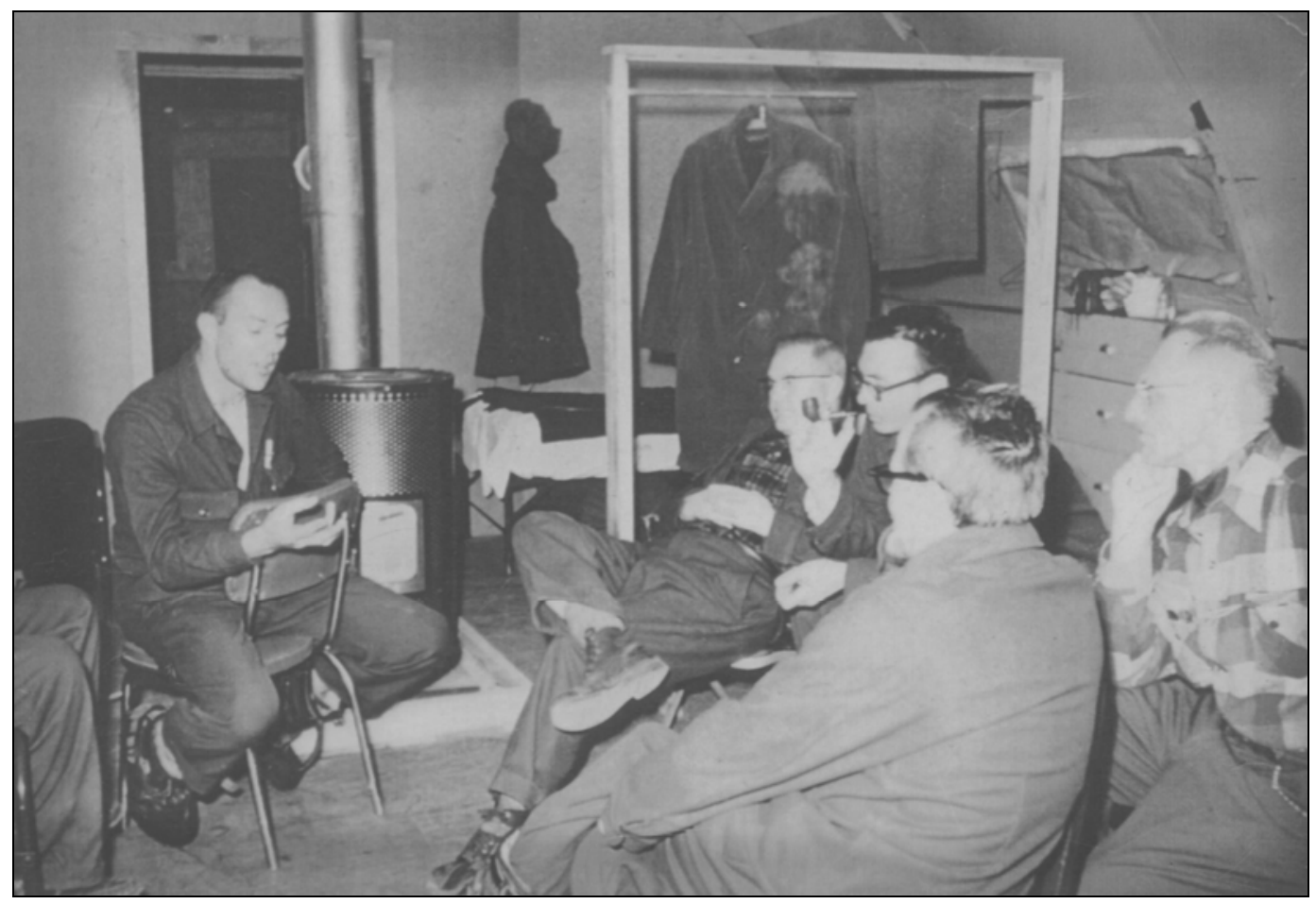

Figure 10. Briefing in the field for SIPRE science research chiefs at end of site 2 drilling, September 1957. At far right, Dr. Robert Gerdel, Chief, Climate and Environmental Research Branch; front right, Dr. Henri Bader, Chief Scientist; James Bender, Chief, Snow and Ice Research Branch; W. Keith Boyd, Chief, Frozen Ground Research Branch; left, Chester Langway, Jr., project leader of ice core studies. 


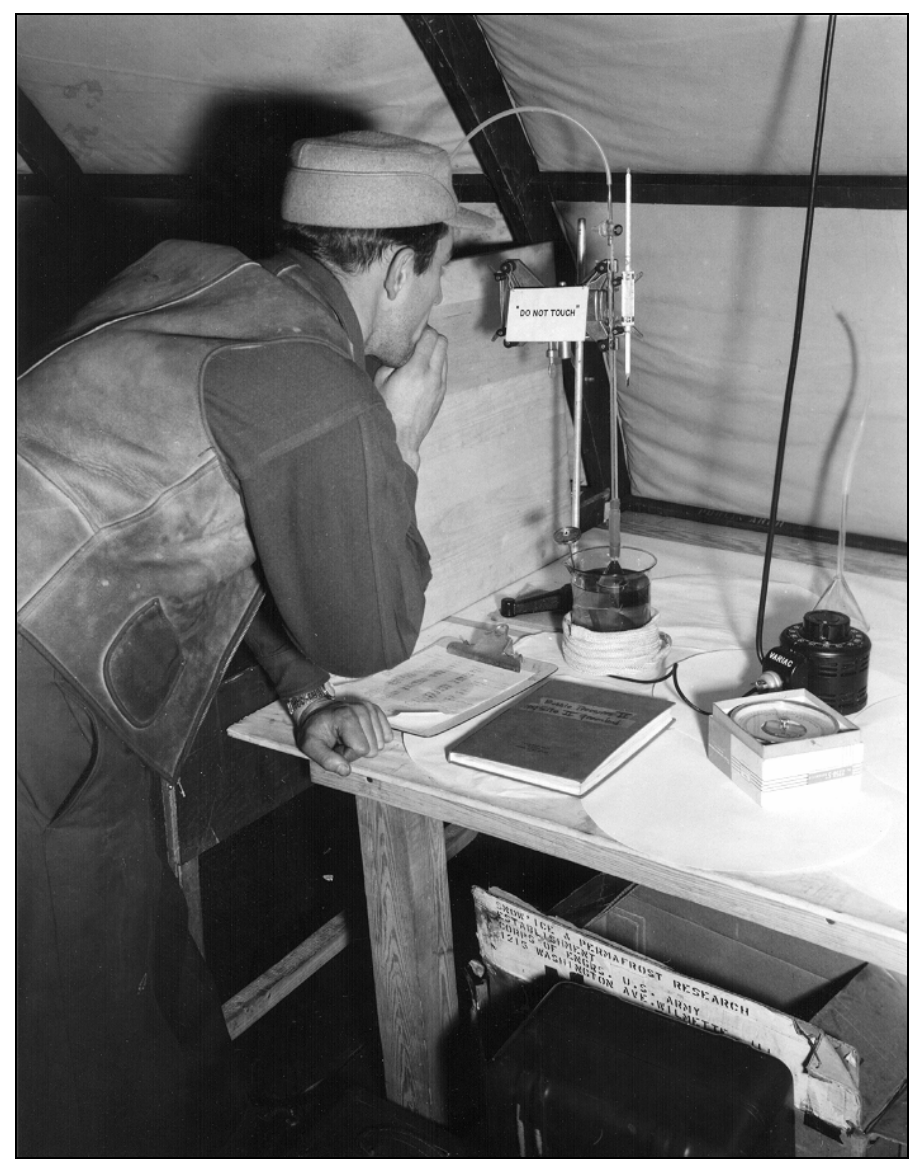

Figure 11. Bubble pressure measurements in the Jamesway field laboratory used to study changing stress relaxation in ice core samples.

Bubble pressures were calculated and plotted versus load. The experiments were repeated in the Wilmette coldrooms 12 and 18 months later (Langway 1958b, Bader 1958, 1965). Embedded particle concentrations were made in the field by melting core specimens and concentrating the particles using a Millipore filtering apparatus. Thinsection crystal analyses were also made at selected core depths, using a "universal-stage" (Langway 1958c). Cooperative studies were later made on the approximately 900-year-old ice core profile, with samples provided to Epstein for measurements of the stable oxygen isotope ratios (Fig. 12) (Epstein and Sharp 1959, Langway 1962, 1967) and to the Russell Werby Laboratory (J unge 1957, 1960) for measuring the ionic concentration levels on horizontally adjacent core samples. This complete investigation (Fig. 13) marked the first, state-of-the-art, integrated scientific investigation of a deep ice core. A full report of the Site-2 core study by Langway was published both at CRREL in 1967 and as Special Paper 125 by the Geological Society of America (GSA) in 1970. The Greenland 
drillings were closely followed by the successful IGY core drillings in Antarctica, at Byrd Station in 1957-1958 (307 m) and at Little America V, on the Ross Ice Shelf, in 1958-1959 (264 m, into seawater). Robert

Patenaude (Patenaude et al. 1959), Richard Ragle (Ragle et al. 1960) and Lyle Hansen were the drillers. Marshall $(1959,1962)$ and Anthony Gow (Bender and Gow 1961, Gow 1961, 1968) processed and recorded the ice cores.

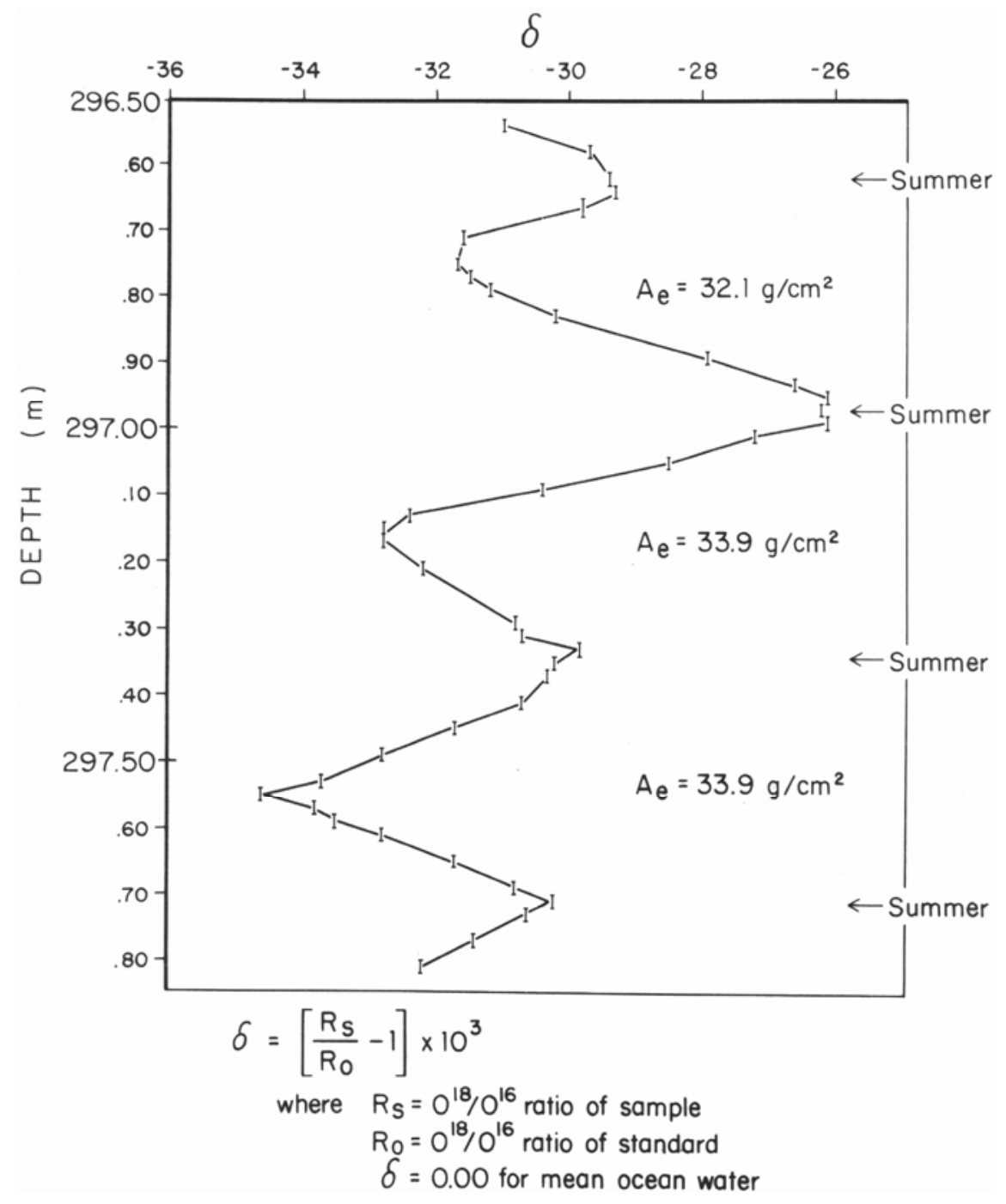

Figure 12. Plotted results of stable oxygen isotope ratio measurements on a continuous ice core interval from $300 \mathrm{~m}$ deep for the Site 2 core. $A_{e}$ is the annual past snow accumulation, in water equivalent, for these approximately 725-year-old snowfall layers (Langway 1967). 


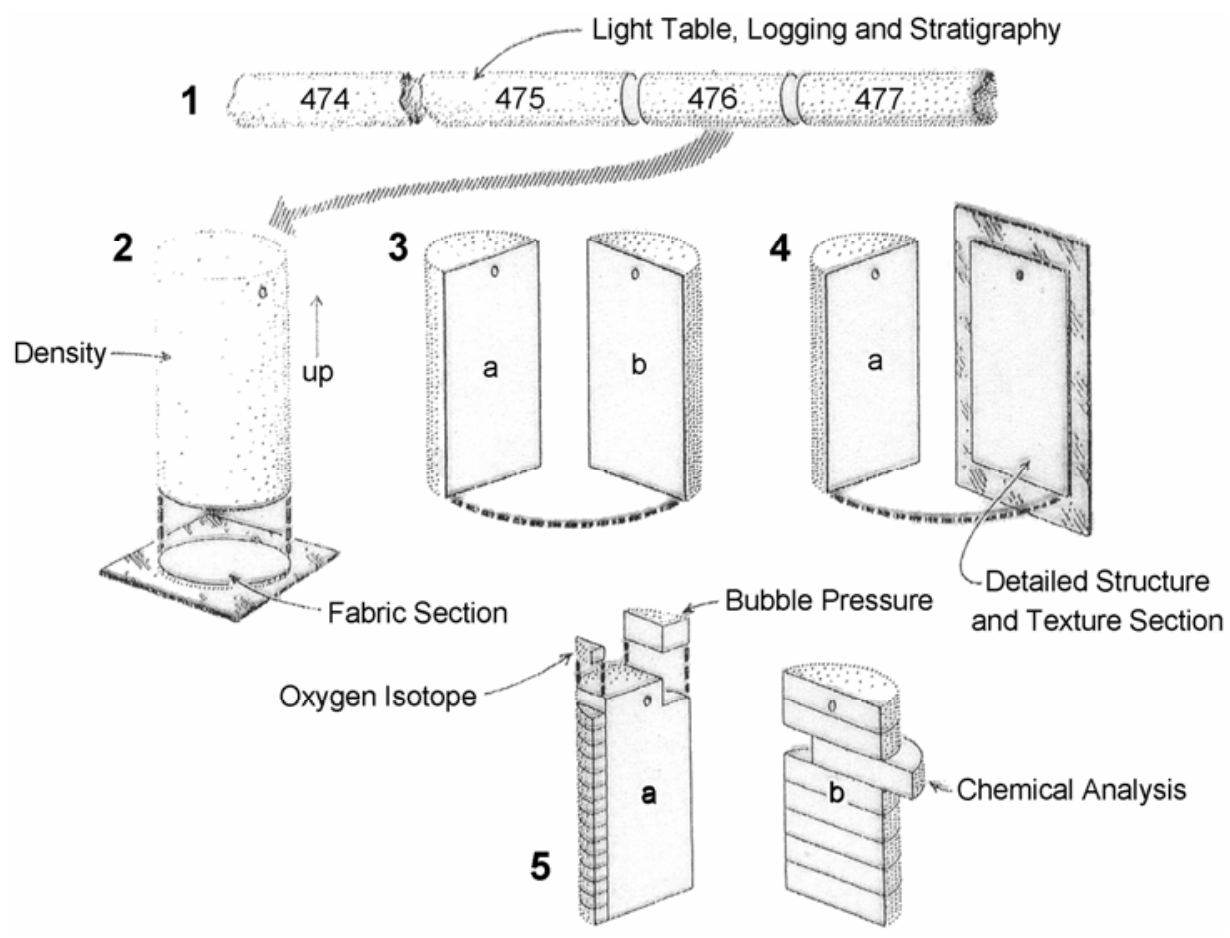

Figure 13. Schematic diagram illustrating the approach and procedures used to investigate the Site 21957 ice core. (From Langway 1962.) 


\section{Post-IGY Bedrock Cores}

The overall successes of SIPRE's core drillings and early core analyses in Greenland and Antarctica during the IGY programs received widespread interest and approval. The U.S. National Academy of Sciences/ Committee on Polar Research (NAS/CPR) adjudged the results significant and meriting their highest recommendation for SIPRE to develop a post-IGY deeper ice coring system capable of reaching bedrock depths (Gould 1970). The international glaciological community also took favorable notice of SIPRE's research results. They are reported to have influenced or reinforced the interests of at least 12 other countries, including Denmark, Switzerland, the Soviet Union, Australia, France, J apan, New Zealand, Belgium, England, Canada, Chile, and Iceland, in drilling for ice cores between 1958 and 1984, in the polar, subpolar, and alpine regions of both hemispheres (Mitchell and Kellogg 1984). Once started, ice core drilling and science began to embark on a life of its own.

Bader (1962) and Hansen (1994) had anticipated the need for a larger, more powerful core drilling system to reach bedrock depths and had already jump-started the planning stage during the IGY operations. Looking ahead, they began to develop component systems for a deeper thermal coring drill for use by CRREL at Camp Century, Greenland, and Byrd Station, Antarctica. At the same time, Hansen and crew built, or provided blueprints for, several operationally tested intermediate-depth (300$500 \mathrm{~m}$ ) thermal coring drills for use in dry-hole drilling operations by Australian, Canadian, Icelandic, and J apanese researchers (Hansen, personal communications).

The first leg of the CRREL post-IGY bedrock core drilling project originated at Camp Tuto, at the edge of the ice sheet on the trail to Camp Century, in the summers of 1959 and 1960. Here the preliminary testing of the new concept of a cable-suspended deep thermal coring device, for use in a fluid-filled hole, was conducted. The operation then moved to Camp Century (Fig. 14, 15, 16) in the fall of 1960 in preparation for drilling the next summer (Ueda and Garfield 1969a). Three ice cores (12.4- $9.1 \mathrm{~cm}$ diam.) were finally recovered at Century using the new thermal deepcoring system (Fig. 17). The first hole, in 1961, reached $186 \mathrm{~m}$, where the drill got stuck and the hole was abandoned; another new hole was started 


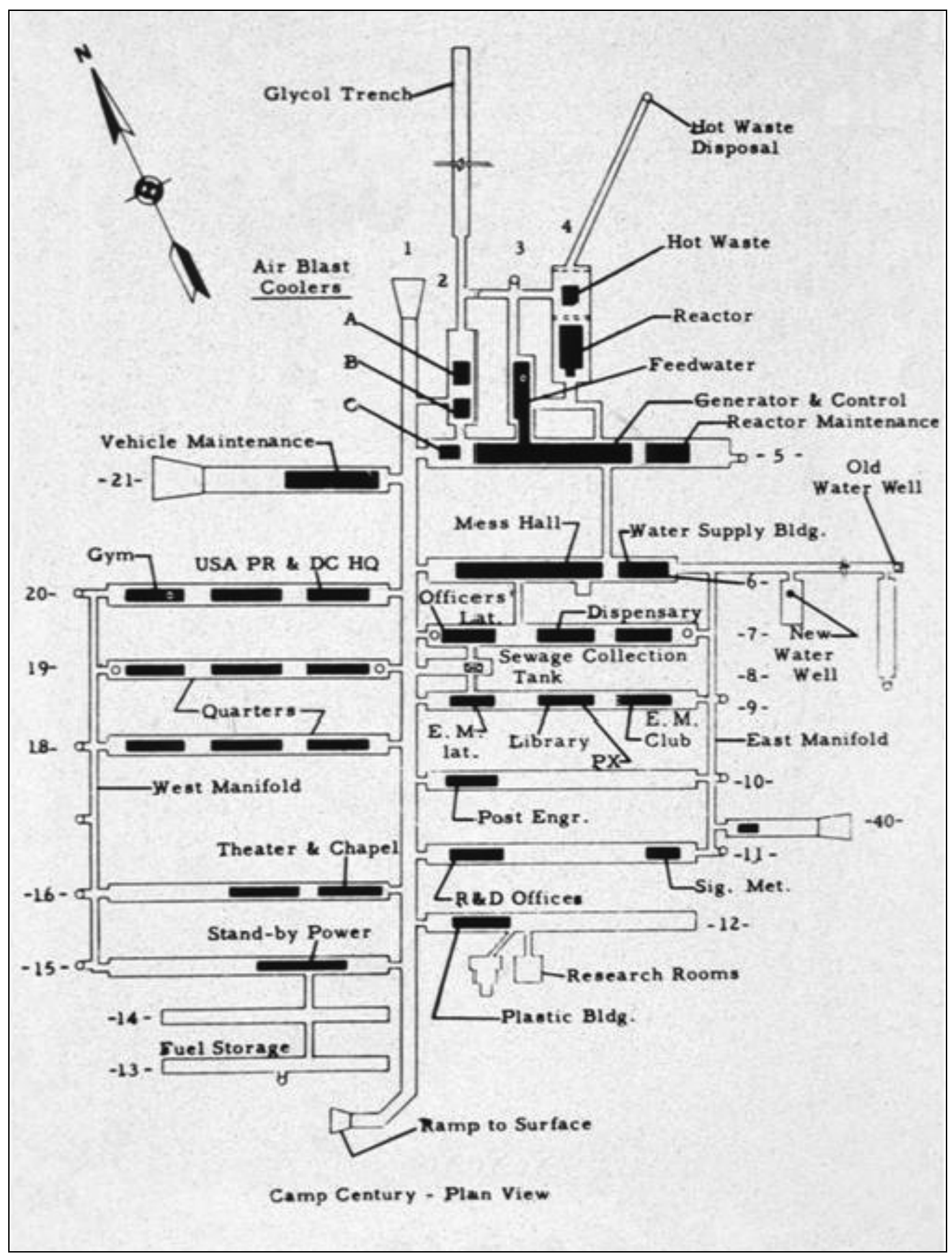

Figure 14. Plan view of the sub-ice configuration of the Camp Century facility. Core drilling was conducted in Trench 12. A warm-room science laboratory was established in Trench 11. The particle collection site was at the old water well located to the rear of the mess hall in Trench 6. 


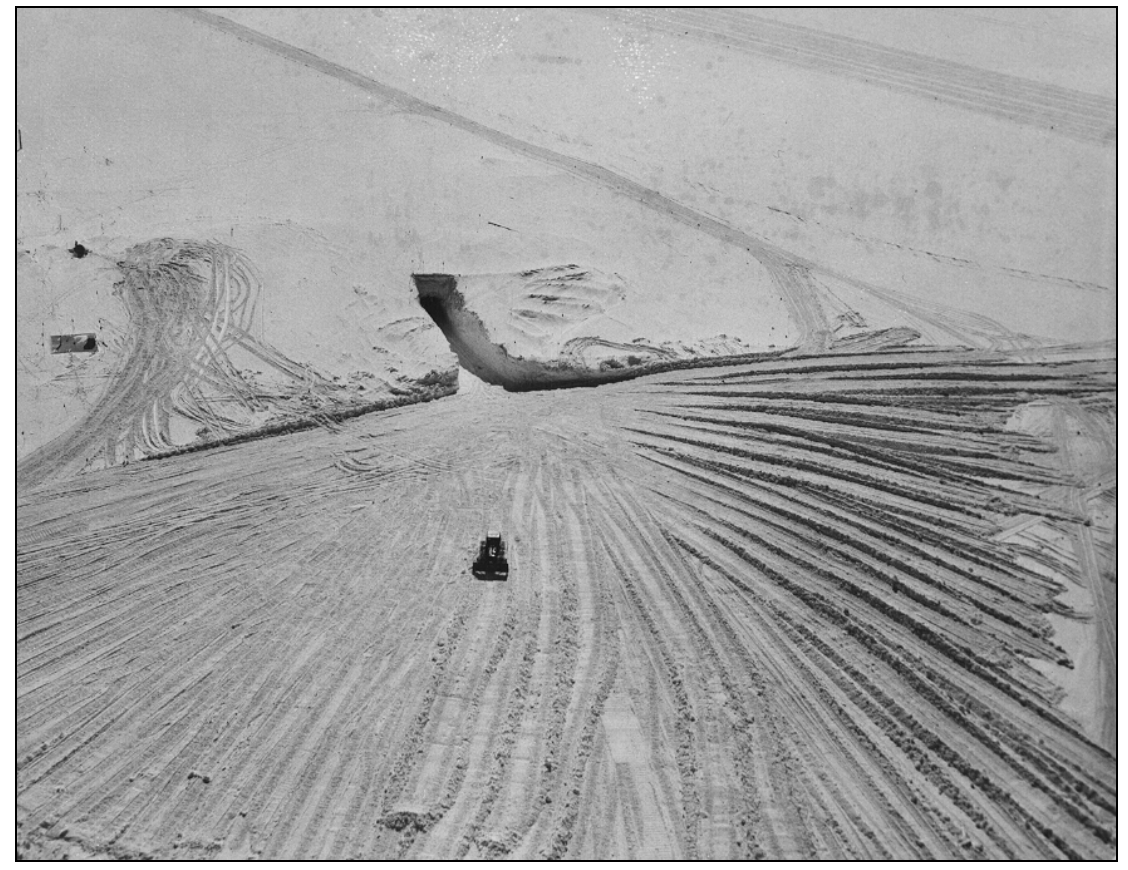

Figure 15. Surface view of the ramp entering below surface Camp Century complex, 1964. The D9 Caterpillar tractor is clearing snowfall and drift to allow easy access to the entrance.

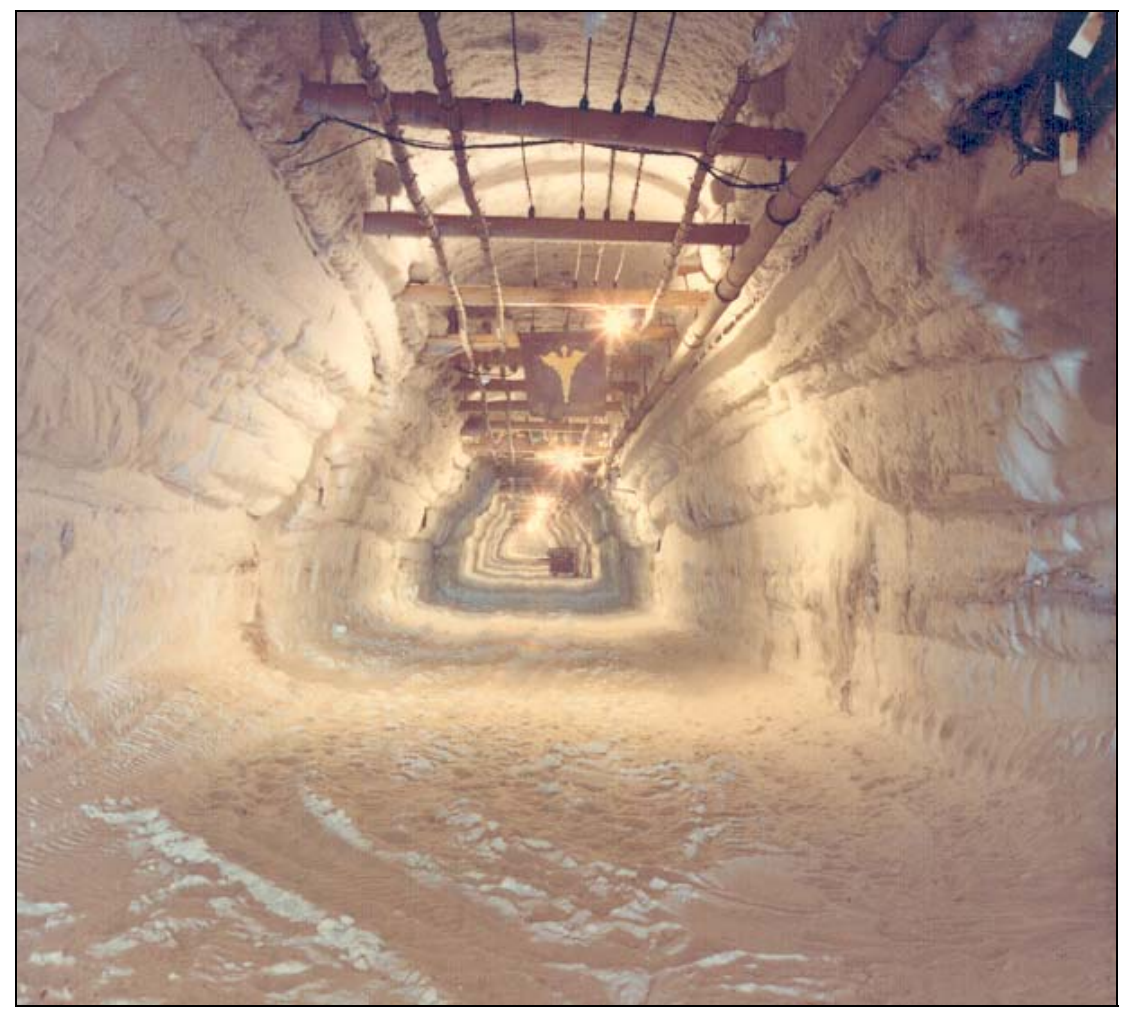

Figure 16. Main 400-m-long access trench below the surface at Camp Century, 1964. More than a dozen, 150-m-long side trenches radiated out from the main trench. 


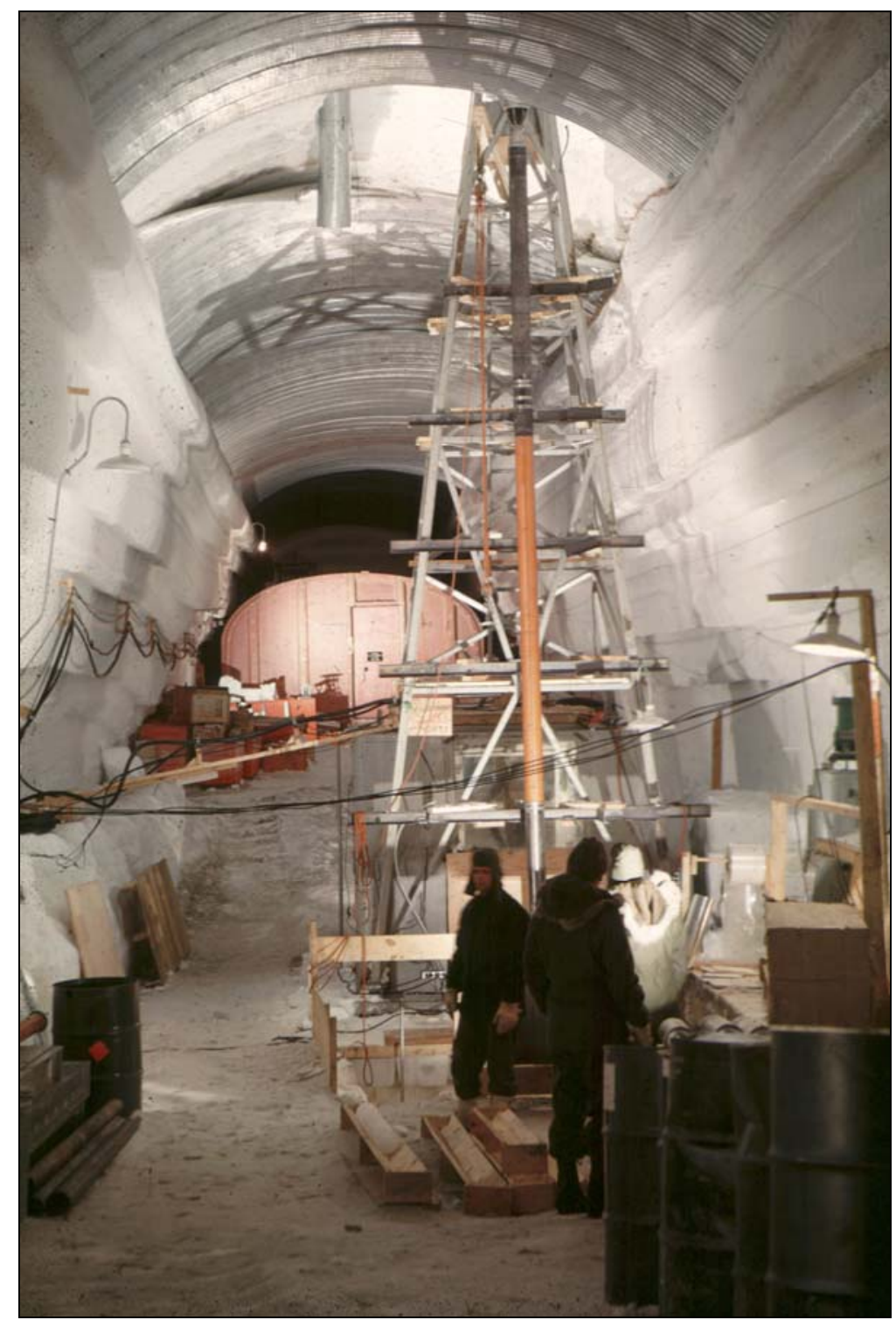

Figure 17. Thermal coring rig in Trench 12 at Camp Century, 1964. Senior Engineer $\mathrm{H}$. Ueda (back to camera) and Specialist W. Vest are standing next to the ice core increments in carriers. The orange composite building at the rear is the driller's work shop.

in 1962 and reached $238 \mathrm{~m}$, where the heating head was lost and the hole abandoned; a third hole was started in 1963, which reached $264 \mathrm{~m}$. The 1963 hole was re-entered using the thermal drill in 1964 and extended to $535 \mathrm{~m}$. In mid-1965, because of the unsatisfactory slow rate of core recovery and the complications of operating the experimental thermal drill in a fluid-filled borehole, the thermal drill was replaced with a newly acquired and modified electro-mechanical drill. The "Electrodrill" was inserted into the 535-m-deep hole to continue coring (9.1 cm diam.), and it reached the base of the ice sheet in J uly 1966, at 1387 m (Hansen and Langway 1966). 
The total experimental drilling operation took a strenuous six-year field effort by the crew to recover the first-ever continuous ice core to bedrock. The crew consisted of Project Leader Lyle Hansen and engineering associates, including Senior Engineer Herbert Ueda, J ohn Kalafut, Donald Garfield, and Haldor Aamot, all of CRREL, along with several military technical support assistants (Ueda and Garfield 1968).

During the core drillings at Camp Century, Langway, with military support assistants Specialists William Vest and Edward Bondurant (PRDC) and others, was responsible for the ice core processing and other field measurements (Langway 1962, 1968). Field processing consisted of passing the entire fresh core increments across a transmitted light source (from below) to visibly observe, to log and record in detail, and to photograph any preserved macroscopic features of deposition or metamorphosed relics. Other measurements included continuous bulk densities at selected depths, as well as crystal size and "c"-axis orientations.

Auxiliary studies were also conducted to micro-filter some of Camp Century's daily water supply of 12,000-15,000 gallons of well-water per day, provided by steam-melting deep-seated glacial ice using a technique developed by Rodriguez (1963) (Fig. 18), to collect extraterrestrial and terrestrial dust particles. This study was jointly developed and conducted with Edward Fireman of the Smithsonian Astrophysical Observatory, Cambridge, MA. A large-diameter, commercial micro-filtering apparatus was inserted into the water line near the trench-level well-breakout point (Fig. 19) (Wright et al. 1963, Langway and Marvin 1964, Langway and Fireman 1966, Fireman and Langway 1965, McCorkell et al. 1968) An attempt was made to recover larger dust particles (anticipated to be up to millimeter diameters or greater) by lowering a manned "boatswain chair" from the trench floor level down to the water-well ( $85 \mathrm{~m}$ below trench level, with about a 25- to 31-m "oval-lake outline"). A hoisting cable and winch was used to lower and raise the "chair," which included an extended power cord to operate a strong vacuum-suction apparatus and a particlefree magnetic device (McCorkell et al. 1968). Collections were also made for radioactive dust particles from several other ice sheet sources (Langway 1963, Crozaz and Langway 1966, Crozaz et al. 1966, McCorkell et al. 1967, 1968, Hodge et al. 1964, 1967, Koide et al. 1997). 


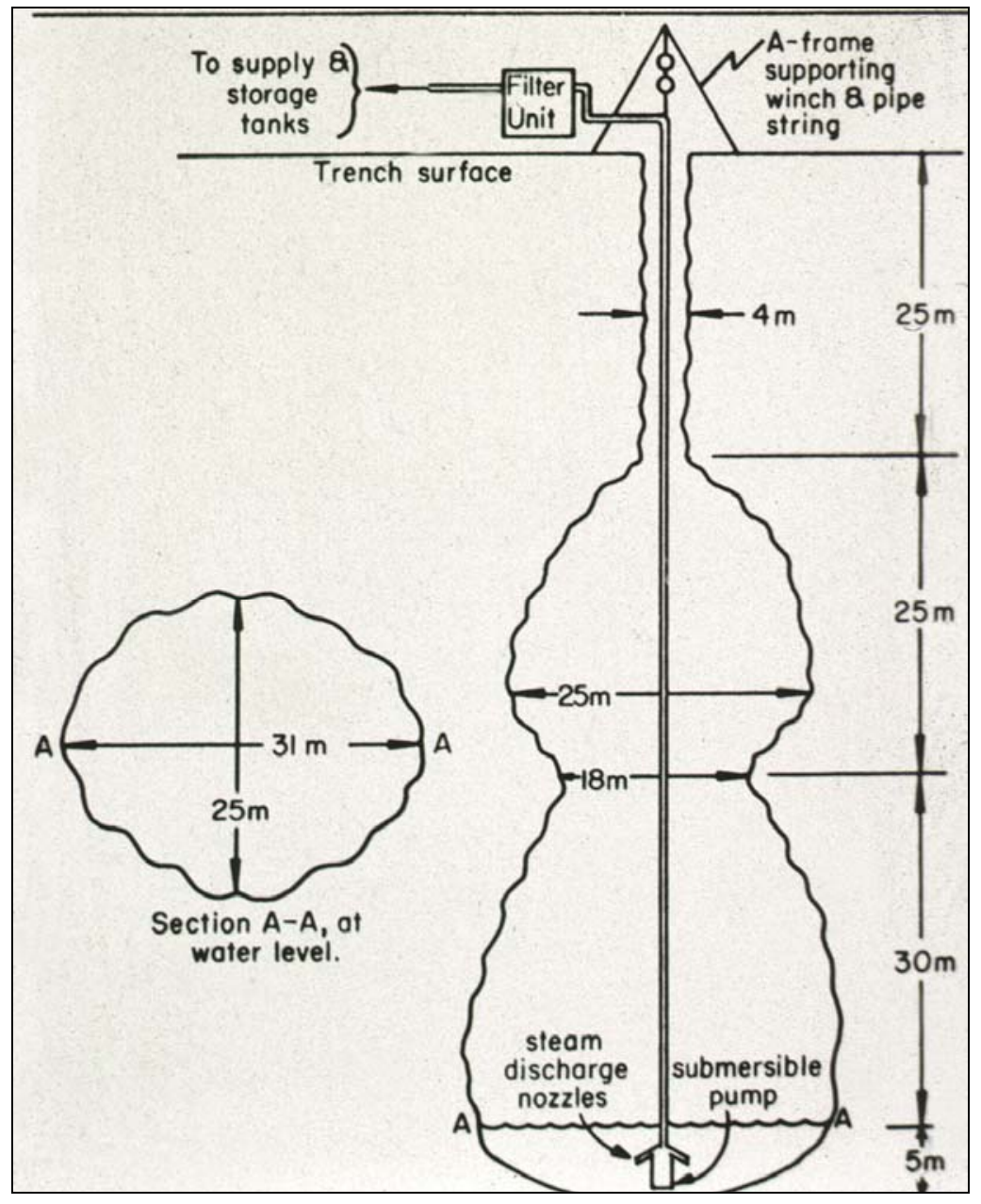

Figure 18. Cross section of Camp Century's water well, 1963.

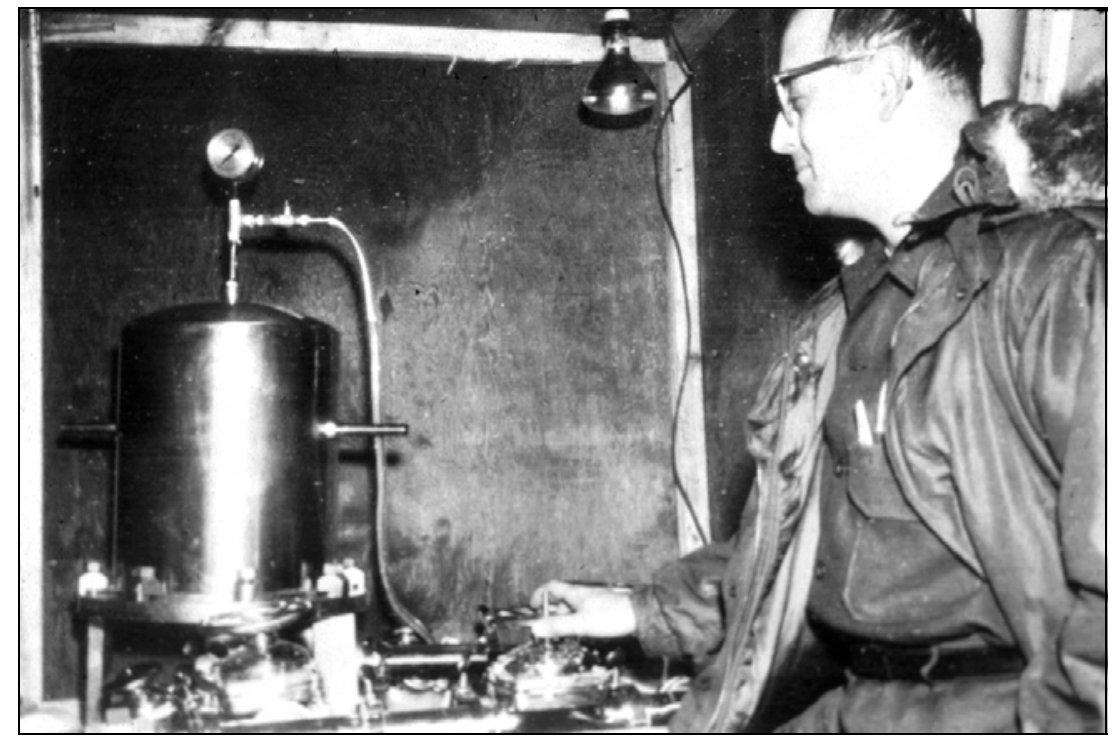

Figure 19. E.F. Fireman, Smithsonian Astrophysical Observatory, at a trench-level water-well breakout station and a micro-filtering system, 1963. 
The same Electrodrill used at Camp Century, and the same drilling team of Hansen, Ueda, Kalafut, Garfield, and Aamot, went to Byrd Station, Antarctica, in the fall of 1966 for the second leg of the post-IGY project. They successfully reached bottom ice at Byrd Station at $2164 \mathrm{~m}$ in J anuary 1968; incredibly, it took less than parts of two field seasons (Ueda and Garfield 1969b). Gow and Specialist Roger Doescher processed and recorded the ice cores (Gow 1970). In the 1969- 1970 field season, the drill was lost after re-entering the borehole and attempting to recover a core from below the glacier/ sub-ice boundary, when the glacier/ sub-ice interface meltwater unexpectedly gushed up into the borehole and froze in the core barrel. Several attempts to recover the core barrel with special tools were unsuccessful. The cable was severed at $1545 \mathrm{~m}$ to enable the continuation of borehole closure and ice flow measurements, but this resulted in forfeiting CRREL's only bedrock drilling rig. 


\section{Laboratory Analyses}

The multidisciplinary laboratory analyses of the Camp Century ice core continued in the fall of 1966, soon after the entire ice core shipment from Greenland arrived at CRREL, Hanover, NH (Fig. 20). Ever since the ice core research program evolved and expanded, Langway reached out to other U.S. (19) and foreign (9) scientists or institutions to encourage and solicit new research expertise, especially with researchers having established laboratories in critically important fields of research not available at CRREL (Langway 1958a, Langway and Hansen 1970). National and international collaboration in glaciological research is a long-held tradition with many mutual benefits (Gould 1970).

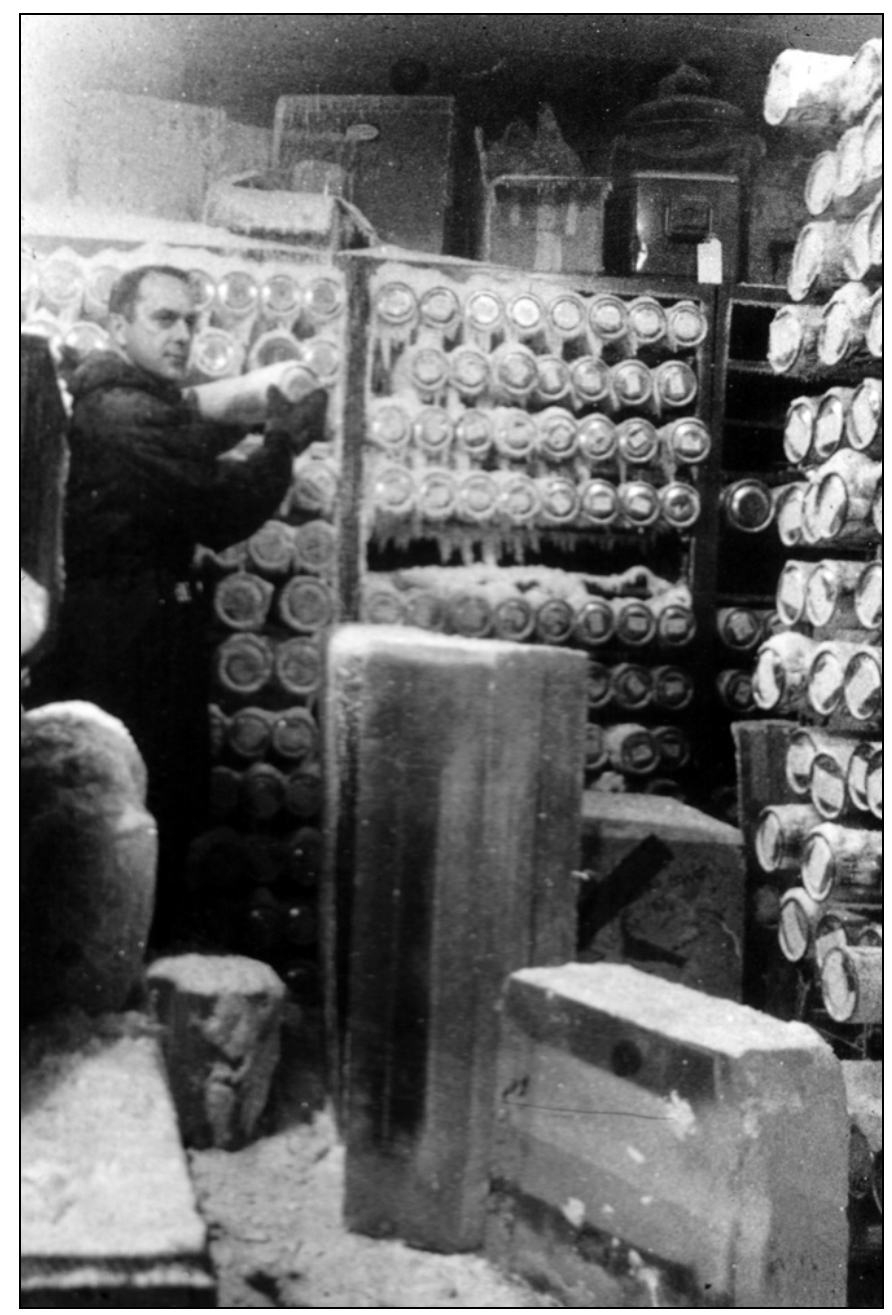

Figure 20. One of the ice core storage freezer compartments at CRREL, 1965. 
By 1966 Willi Dansgaard and associates, at the University of Copenhagen, had already been operating a successful high-capacity, well-established mass spectroscopy laboratory for over a dozen years, and they were then measuring oxygen isotope ratios on Danish samples of glacier ice from Greenland, as well as on a world-wide collection of water samples on an IAEA (International Atomic Energy Agency) contract. Dansgaard made contact with CRREL at this time, visited the laboratory, and joined Langway in the ice core study program as a professionally accomplished and productive leader in the evolving research coalition (which extended over a 23-year period) on a cost-sharing basis. A few years later Dansgaard's laboratory, coupled with the technical ingenuity of Sigfus J ohnsen and Neils Gundestrup, was capable of automatically measuring 250 melted ice core samples for ${ }^{18} \mathrm{O} /{ }^{16} \mathrm{O}$ ratios per day-a remarkable research feat then and now. Dansgaard's entire program of measuring thousands of oxygen isotope ratios in the initial study of the bedrock Camp Century core (Dansgaard et al. 1969, 1971) and later on the bedrock Byrd Station core (J ohnsen et al. 1972), after an earlier oxygen isotope study was completed (Epstein et al. 1970), was fully supported by Danish funds, as were the tens of thousands of samples measured on all four GISP deep ice cores, including the bedrock core from Dye-3, where 70,000 samples were continuously measured (Dansgaard 2004).

Hans Oeschger and Langway met at an International Glaciological Society symposium held in Obergurgl, Austria, in the fall of 1962. They discussed their mutual interest in the entrapped atmospheric air bubbles in polar glacier ice (Langway 1958b, 1962). Oeschger introduced the possibility of measuring the chemical composition of the gaseous content and dating the $\mathrm{CO}_{2}$ component of the air bubbles. He suggested it could be possible by a new ${ }^{14} \mathrm{C}$ technique he had developed at his unique low-level carbon-dating laboratory at the University of Bern. Oeschger, at that time already a professionally accomplished and experienced carbon-dating researcher, became a valuable leader in the CRREL ice core research coalition (which extended over a 27-year period) on a cost-sharing basis. Oeschger and associates were first in developing techniques to extract and precisely measure the ${ }^{14} \mathrm{C}$ activity in the $\mathrm{CO}_{2}$ extracted from polar ice cores. Soon after, Oeschger was a pioneer in measuring $\mathrm{CO}_{2}$ and $\mathrm{CH}_{4}$ concentrations in ice core samples as a function of depth/ age in order to reconstruct the atmospheric greenhouse gas concentrations of the past (Berner et al. 1980, Oeschger 1985, Oeschger and Sigenthaler 1988, Oeschger and Langway 1989, Stauffer 1985, Stauffer et al. 1988). J oint field trips were taken to 
Greenland in 1964 (Langway et al. 1965) and in 1965 (Oeschger et al. 1966), and then to Antarctica in 1968-1969, with Oeschger, B. Stauffer, H. Steuri, and others, to obtain core samples and large volumes of prehistoric atmospheric gases, using a unique down-borehole gas extraction system (Oeschger et al. 1967, Langway et al. 1969). 


\section{Greenland Ice Sheet Program}

In the early spring of 1970, a group of scientists and engineers from the United States, Denmark, and Switzerland gathered to discuss the possibility of conducting a new major ice core drilling investigation of the entire Greenland ice sheet. Based on their accumulated research experience, acquired by successfully working together for several years, they debated the possibility and benefits to be gained by pooling their field and logistical bases, science specialties, laboratory facilities, and possible financial support to carry out the research. The ambitious program would be based on, and directed toward further investigating, the fuller scope, extent, and reproducibility of the new climatic and other environmental records that were discovered in the Camp Century and Byrd Station cores. Out of this meeting, the group conceived, planned, and developed the Greenland Ice Sheet Program (GISP). The GISP concept and action plan was presented and reviewed by officials of U.S. NSF's Division of Polar Programs (J oseph Fletcher, Director) in the fall of 1970. GISP was presented as a joint, international, coordinated, interdisciplinary and multifaceted, cost-sharing investigation. CRREL was identified as the lead laboratory (Hansen and Langway, co-PIs), with major contributions from the University of Copenhagen (Dansgaard, co-PI), the University of Bern (Oeschger co-PI), and the remote sensing capability for the ice sheets airborne depth-soundings by the Technical University of Denmark (Preben Gudmansen, co-PI). The logistics and field support would be arranged by U.S. NSF mainly using PICO (the Polar Ice Coring Office) at the University of NebraskaLincoln (J ames H. Zumberge and Robert H. Rutford, Directors, and J ohn Splettstoesser and Karl Kuivinen) and contracting with the U.S. Air Force Air National Guard's 109th Air Lift Wing, using LC-130s with ski-equipped landing gear, to provide the program's supply and transport needs. Initially, the $109^{\text {th }}$ home base was in Alaska; later it was in New York state. A comprehensive science plan was prepared (Langway 1976) and submitted to all national science oversight committees and funding agencies for review and acceptance (in the U.S., Robert Rutford, Director of NSF's DPP). Final approval was given in the U.S. by NSF's National Science Board; Langway was appointed Chief Scientist of the U.S. GISP participants. 
The entire GISP operation required an 11-year field period (Appendix A). The first seven years were occupied by various preparatory and auxiliary science studies in both the field and laboratories to garner more original regional field and theoretical data to determine the optimal deep drilling site locations. Airborne radar depth-sounding surveys were made (Gudmansen 1973, 1975, Gudmansen et al. 1975), and many surface geophysical, glaciological, and theoretical studies were undertaken during this period (Steven Mock, William Hibler, J ohannes Weertman, Edward D. Goldberg, Min Kodie, Clair Paterson, Ian Whillins, Neils Reeh, J . Beer, Bruce McInnes, C. Boutron, Uwe Radok, and Kenneth J ezek; see Langway et al. 1985). Three intermediate-depth thermally augured ice cores (12.7 cm diam.) were first obtained by Lyle Hansen and J ohn Rand, assisted by Robert Bigl, all of CRREL, and others: at Dye 3 in 1971 (372 m), at Milcent in 1973 (398 m, Fig. 21, 22), and at Crete in 1974 (405 m; Fig. 23, 24) which is in the general vicinity of Station Eismitte (Fig. 4). Three bedrock core drillings were originally planned for GISP, but the program was reduced to one location, primarily because of U.S. NSF financial constraints. Although available GISP data, laboriously gathered over the first seven years, pointed to the optimum site location for the first deep drilling to be in north-central Greenland, the financial restrictions forced the selection of the logistically convenient Dye-3 location (Fig. 25, 26) (Weertman 1978). The prime GISP north-central site location was later selected, more than a decade later, and successfully drilled to bedrock at two locations approximately $30 \mathrm{~km}$ apart by GRIP, a multinational European university consortium in 1992 (3029 m), and by GISP-2, a combined U.S. university team in 1993 (3053 m), representing the fourth and fifth ice cores recovered to bedrock depths at that time (AGU 1998) (Appendix A).

The initial Dye-3 deep bedrock drilling was started in 1979 using a 22.2cm-diam. CRREL thermal coring drill to $77 \mathrm{~m}$ (Rand 1980). This was done to insert the large-diameter casing over the porous firn zone to contain the drilling fluid. Thereafter, the newly designed and constructed Danish ISTUK coring auger (Gundestrup et al. 1984, Gundestrup and J ohnsen 1985) was used to drill the Dye-3 core (10.2 cm diam.) to bedrock at 2037 $\mathrm{m}$ in August 1981. Gundestrup and J ohnsen were the primary drillers, ably assisted by Dorte Dahl-J ensen, J.P. Stephenson, J akob Schwander, Henry Rufli (who also assisted as a drill technician), and others. 


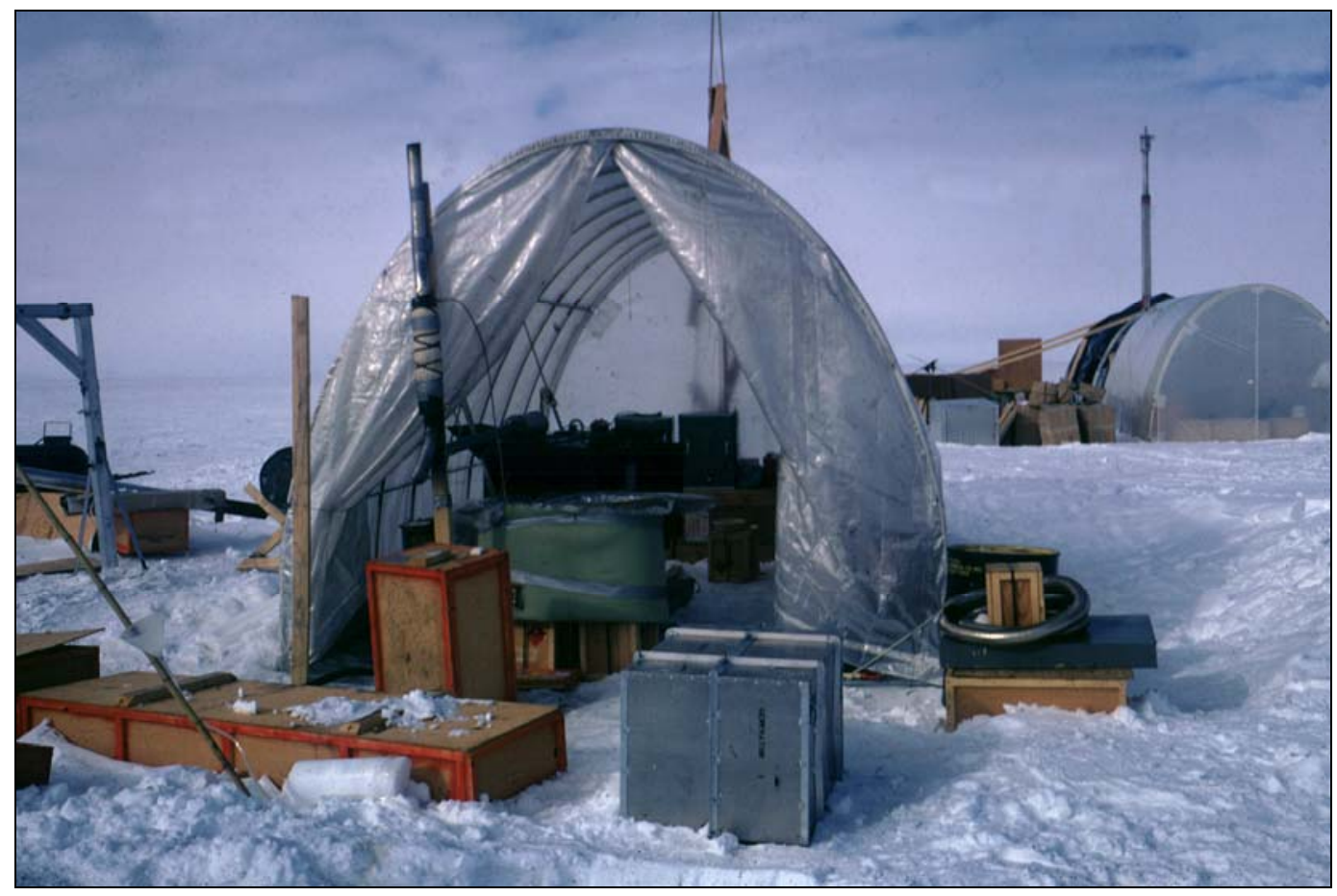

Figure 21. Camp Milcent, 1973. The polyethylene-covered 100-KW generator shelter in the foreground was used for thermal drilling and other camp power needs. Waste heat from generator provided the camp water supply.

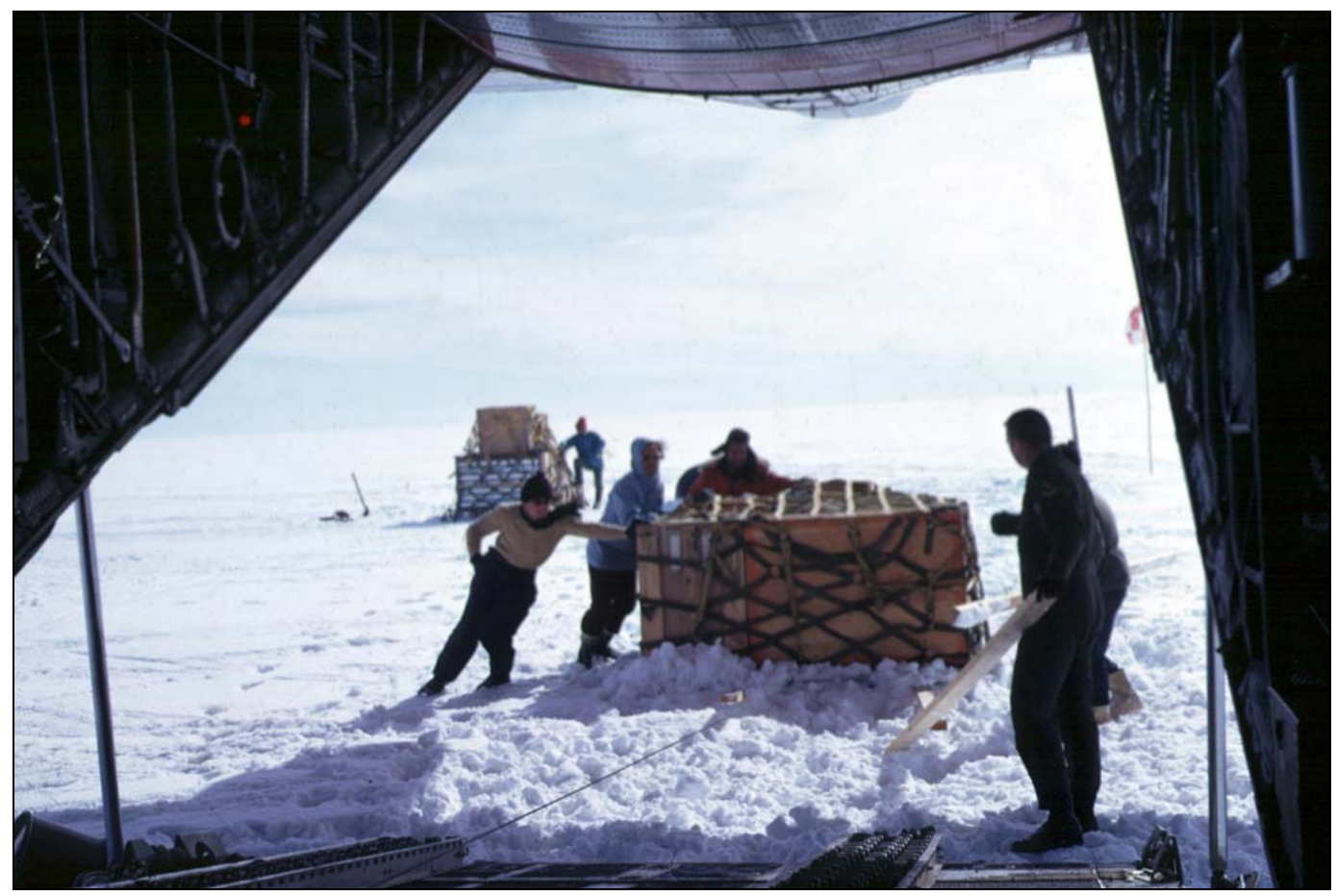

Figure 22. Loading ski-equipped C-130 aircraft with ice cores recovered at Camp Milcent, 1973. Later the cores were temporarily stored in freezers at the Sondrestrom Air Force Base, at the edge of the ice sheet, until the end of the season, when consolidated shipments were made to respective laboratories. 


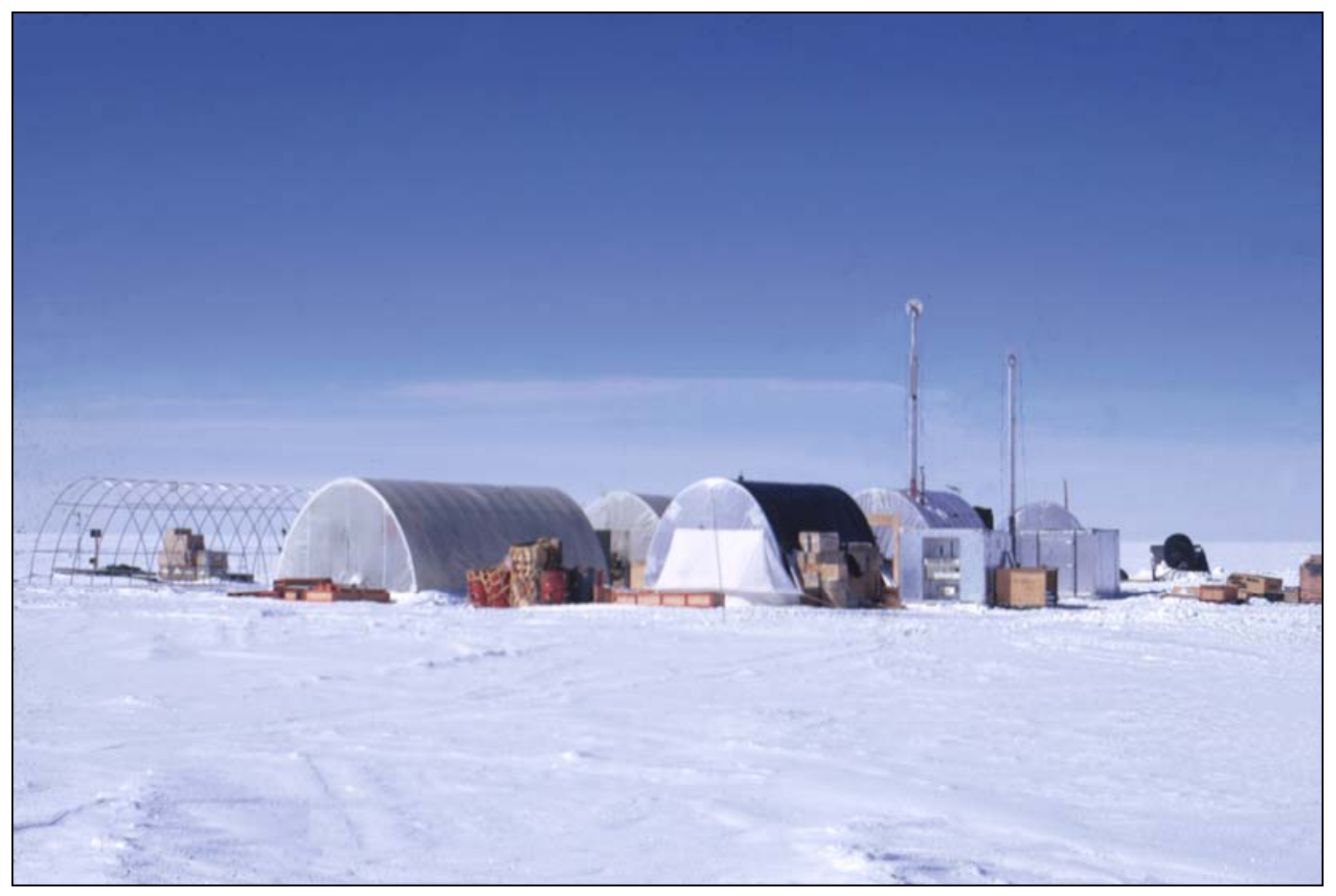

Figure 23. Camp Crete, 1974. The first tower in the background was for the thermal drill; the next tower was for the radar reflector to enable aircraft to locate the site in the middle of the ice sheet.

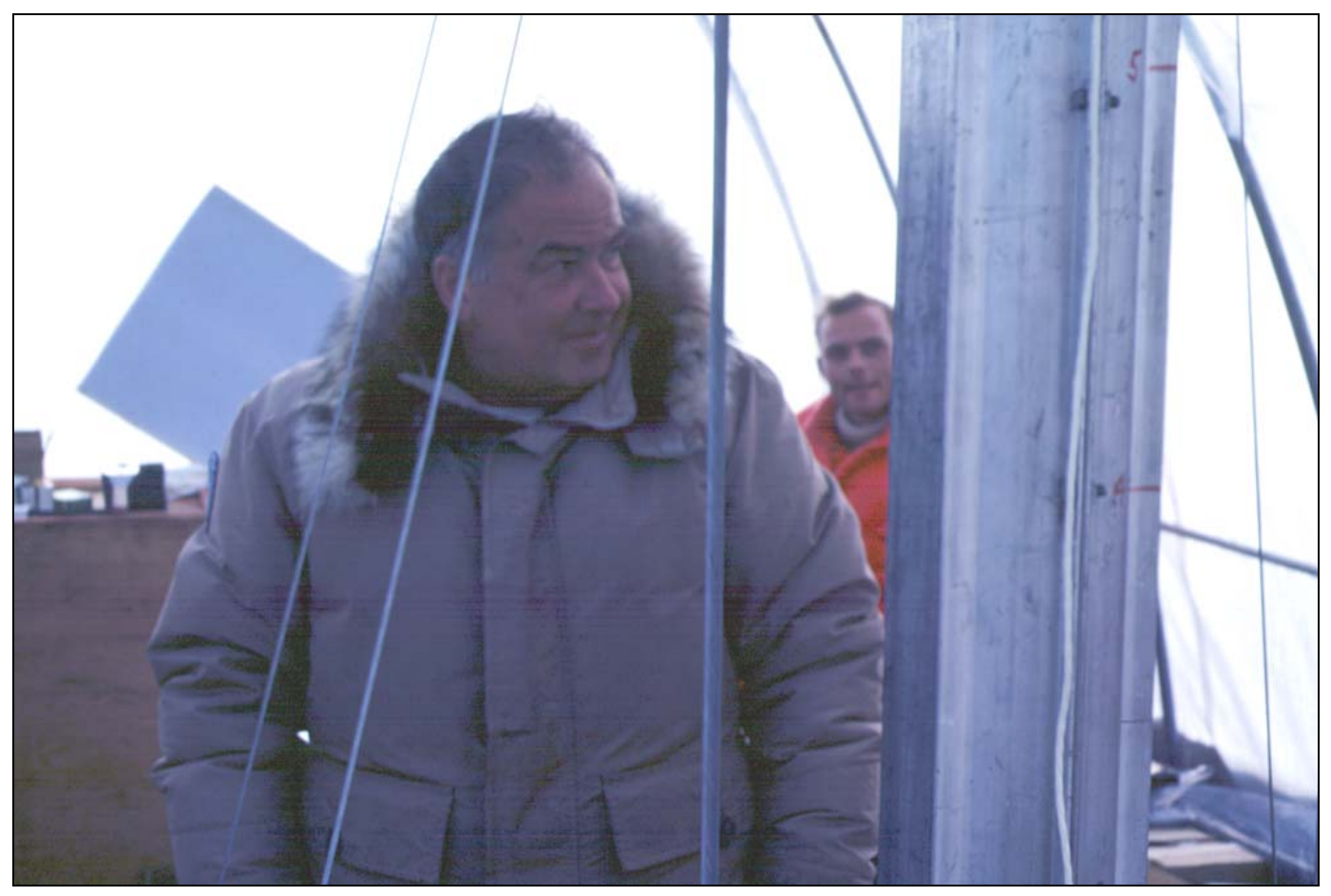

Figure 24. B.L. Hansen at the thermal drilling rig at Camp Crete, 1974. 


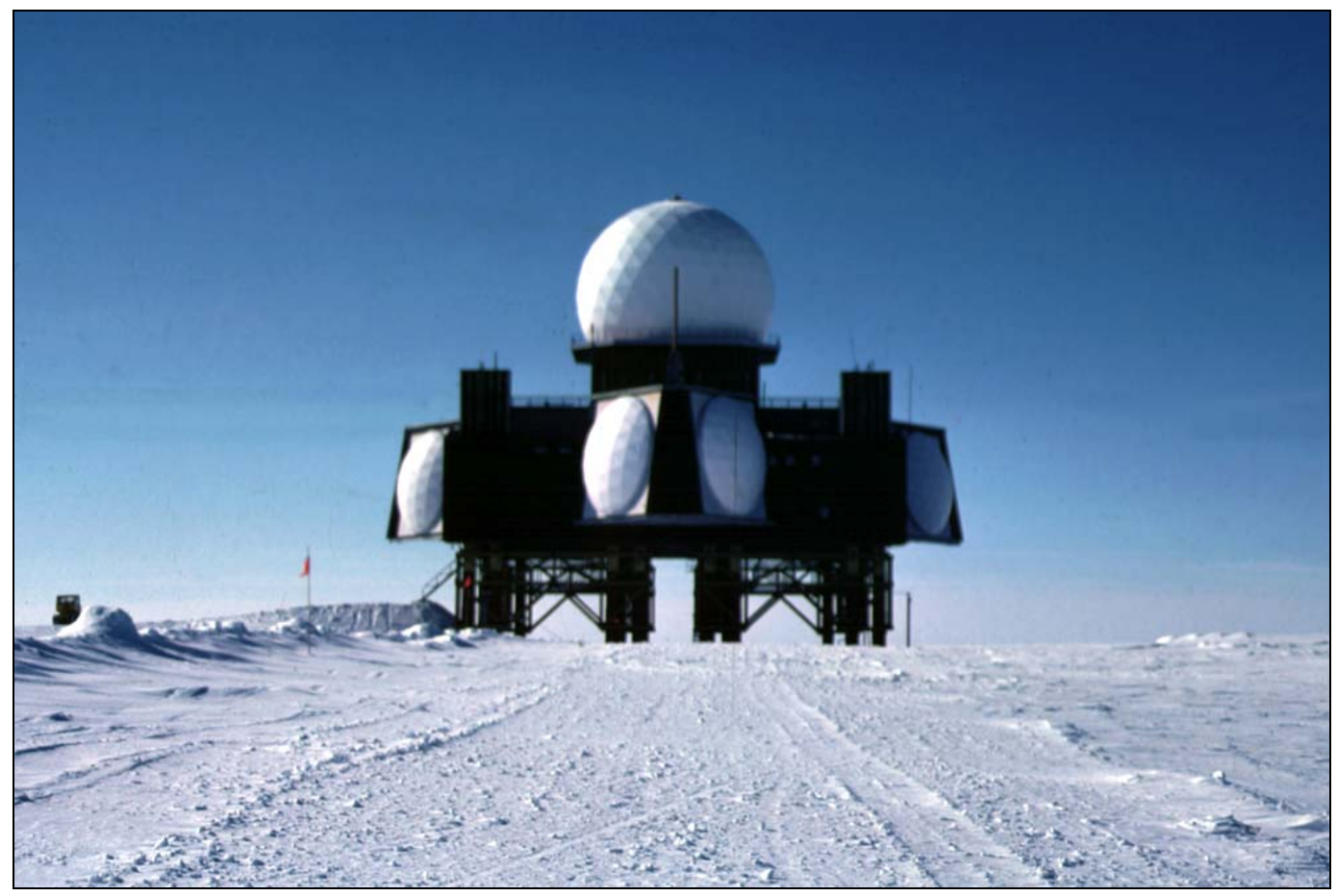

Figure 25. Dye 3, Greenland radar and communications site, 1980. The top of the structure is approximately ten stories high; at the left side is a sloping staircase, about $21 / 2$ stories high, for pedestrian access to the building.

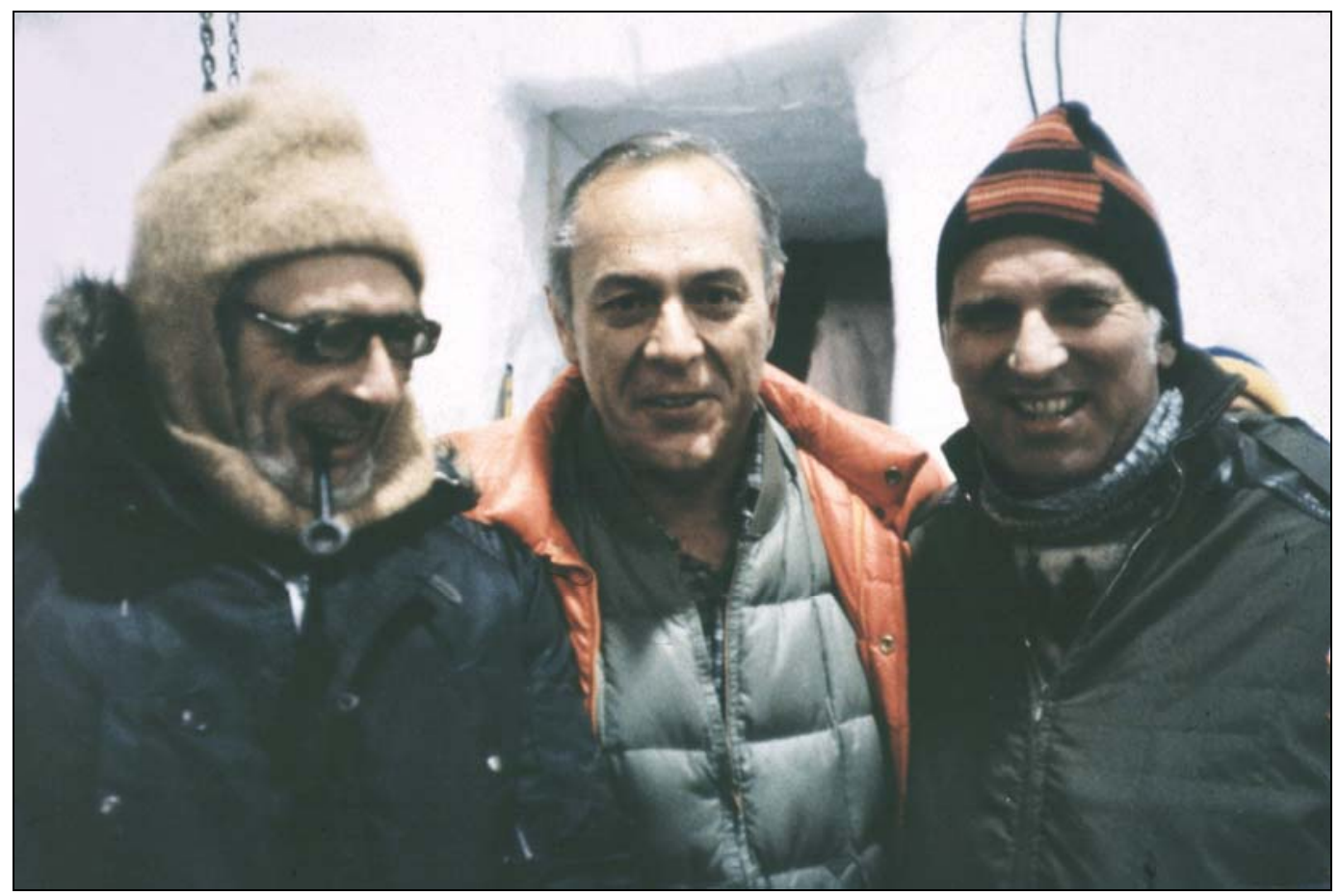

Figure 26. Dansgaard, Langway, and Oeschger in the science trench at Dye 3 shortly after bottom ice was reached at 2037 m on August 15, 1981. (Photo by J. Murray Mitchell, NOAA.) 
An under-snow research laboratory was established on site to examine, record, measure, log, and photograph many of the physical, mechanical, and optical properties of the cores and to prepare tens of thousands of oxygen isotope and other samples [Henrik Clausen, Bernhard Stauffer, Susan Herron (Herron, S.L., and Langway 1982, 1987, Herron, S.L., et al. 1985), Albrecht Neftel, J.P. Steffensen, Palina Kristindottir (Langway et al. 1985)]. The laboratory was also used to prepare and continuously measure micro-particle concentrations and eruptive volcanic-acid horizons by the new electrical conductivity method (ECM) invented by Claus Hammer (Hammer 1977, 1980, Hammer et al. 1980), which proved to be an invaluable tool in resolving the time scale for the 1981 Dye-3 core (Hammer et al. 1985, 1986). A snow cave was excavated off the main science trench to perform instantaneous instrumental mechanical property tests of fresh ice core samples by Hitoshi Shoji (Shoji and Langway 1982, 1987, 1989), Dorte Dahl-J ensen, and J akob Schwander (Schwander and Stauffer 1984).

A prefabricated, heated, cleanroom trailer-laboratory was established and used on the surface by Michael Herron (Herron, M.M, et al. 1981, Herron, M.M., 1982, Herron, M.M., and Langway 1985) and J ames Cragin (Cragin et al. 1974, 1975) and assistants. It was used in the field for the first time to measure the chemical composition of meltwater samples by the new ion chromatography technique. A group of international research associates and students, working in rotation, was also employed to examine and record the cores on an assembly-line series of workstations and to package specimens for transport back to the national laboratories for further study. The procedures set a new standard of efficiency for field studies associated with deep ice core drilling.

All major field objectives and adjusted goals of the GISP field operations were completed on schedule and within budget. Less than one year after the core drilling was complete, initial results were presented in J une 1982 at a special GISP science symposium held in conjunction with the Annual Meeting of the American Geophysical Union in Philadelphia, PA. A symposium proceedings was published: "Greenland Ice Core: Geophysics, Geochemistry, and the Environment" (1985), AGU Geophysical Monograph 33, C.C. Langway, J r., H. Oeschger, and W. Dansgaard, Eds.

In 1986, the GISP accomplishments led to an invitation to Oeschger and Langway from the Dahlem Conference Center, Berlin, Germany (Silke Bernhard, Director), to organize and convene an international workshop 
and symposium to assess and interpret the environmental record in glaciers and ice sheets. The conference was limited to 48 invited internationally recognized participants, selected from various scientific disciplines. The workshop was financed by the City of Berlin and held at the Dahlem Conference Center in March 1988. A proceedings of the symposium was published: "The Environmental Record in Glaciers and Ice Sheets" (1989), H. Oeschger and C.C. Langway, J r., Eds., Dahlem Workshop Report No. 8, Berlin, Germany, J ohn Wiley and Sons. 


\section{Paleoenvironmental Data}

The scientific results of the first deep ice cores recovered from around 300- $400 \mathrm{~m}$, and the very deep ice cores, from 1387, 2164, and $2037 \mathrm{~m}$, have yielded unique windows to past events on Earth and provided the foundation by which many nations have since drilled deep ice cores in both polar regions. The ice core records also have had impacts on a wide spectrum of other scientific disciplines (e.g. geophysics, oceanography, geology, meteorology, climatology, and anthropology) and provide higherresolution data to complement and advance our knowledge gained from studies of lake and marine sediments and tree rings. Many of these investigations continue to this day. Indeed, findings from ice coring science now lay the cornerstone for the formation of global environmental science and policy (IPCC 2001).

Of all the analyses conducted on the first ice core to reach bedrock-at Camp Century, Greenland, in 1966, now over 40 years ago-the original measurements at the University of Copenhagen (Dansgaard, J ohnsen, Clausen, and Moller) marked a singular achievement, producing a record of the annual snow accumulation layers for the past 8,200 years (Dansgaard et al. 1982, Hammer et al. 1986, Morrison et al. 2001, Vinther et al. 2006). Moreover, this original team developed a profile of the complete signature of the late-Pleistocene and Holocene climate cycle (Dansgaard et al. 1970), recording high- and low-frequency climate events and shifting environmental conditions throughout the present Holocene warm period, through the preceding Wisconsin ice age, and into the earlier interglacial warm period, the Sangamon (Eem), at about $115 \mathrm{kyrs}$ BP. This seminal research established the first reliable dating sequences for the Greenland ice sheet's stratigraphic-layer/ depth-age relationships and provided the important and necessary timeline for dating all succeeding paleoenvironmental proxy studies made on the Camp Century core.

Another outstanding original study made on the early ice cores was conducted at the University of Bern, where researchers were first to successfully develop methods to precisely measure the concentration levels of atmospheric gases, especially the "greenhouse" gases, entrapped within the stratigraphically dated ice core layers (Berner et al. 1980, Oeschger 1985, Oeschger and Sigenthaler 1988, Stauffer 1985, Stauffer et al. 1988). 
A third significant original study made on the Camp Century and Dye 3 ice cores by CRREL/ University at Buffalo (State University of New York) was the first measurements of the chemical records of the Earth's changing atmospheric composition with climate change, especially the important events since the Industrial Revolution (Finkel et al. 1986, Osada and Langway 1993, Langway et al. 1994, 1995, Osada 1996) and those related to the sharp and dramatic shift in the trace chemical constituents $\left(\mathrm{SO}_{4}\right.$, $\mathrm{NO}_{3}, \mathrm{Cl}$ ) at the Wisconsin/ Holocene climate boundary (at $1786 \mathrm{~m}, 11.7$ kyrs BP, for Dye3), a remarkably rapid change over a short 10- to 70-year time interval (Herron, M.M., and Langway 1985, p. 78-79). Taken together, these advances made clear that ice sheets were unused, but valuable additions to the limited natural paleodata sources available (Dansgaard 2004, Cox 2005) and, in effect, transformed the ice sheets into virtual databases of detailed Earth history. 


\section{Conclusions}

The successful recovery of the early ice cores during the IGY era advanced a new approach to expose the unknown third dimension of polar ice sheets, and it marked a turning point: Embedded within the interior of polar ice sheets were important and fresh secrets of Earth's history, and these new physical and chemical analyses could reveal them. Ice cores opened a new portal to the past, unsealing continuous long-time prehistorical and geological age records of precipitation, climate, rapid climate change, and natural, artificial and baseline atmospheric chemistry conditions, and more, at the Earth's surface, at the time of snow deposit. In addition, the records bridged a perceived gap in our previous knowledge of Earth history by independently overlapping the important chronological recordings of tree rings and marine/ lake sediments. Finally, the Camp Century ice core provided the first direct evidence that a long-term chronology, in fact, exists within the massive Greenland ice sheet's body, is measurable, and is clearly connected to today's surface as a living relic, into and beyond the last great ice age on Earth. The 1966 Camp Century ice core became the first jewel in the crowning events of deep polar ice core drillings to bedrock and the scientific justification and foundation for the continued ice core research at Byrd Station in 1968 and for GISP and Dye 3 during 1971- 1981 and leading to the future, as discussed by Mitchell and Kellogg (1984) and Weertman (1986). 


\section{Summary}

Deep polar ice cores were first successfully recovered and studied from Site 2, Greenland, in 1956 and 1957 by the U.S. Army Snow, Ice, and Permafrost Research Establishment (SIPRE) and were followed by two others from Antarctica, at Byrd Station in 1957- 1958 and at Little America V on the Ross Ice Shelf in 1958- 1959, ranging in depth from 264 to $411 \mathrm{~m}$. These cores were acquired as part of SIPRE's contribution to the U.S.'s polar latitudes research activities conducted during the Third International Polar Year (redesignated the IGY). The results of the IGY drillings and core studies were encouraging and supported continued post-IGY research to develop a drill capable of reaching bedrock depths. This objective was accomplished by the U.S. Army Cold Regions Research and Engineering Laboratory (CRREL) and resulted in the first successful effort to core drill to bedrock, made at Camp Century, Greenland, in 1966 (1387 m) and at Byrd Station, Antarctica, in 1968 (2164 m). After the progress made during the IGY activities, the Greenland Ice Sheet Program (GISP) was launched in 1971, based on a partnership that had begun in 1962 between CRREL, the University of Copenhagen, Denmark, and the University of Bern, Switzerland (and in 1975, joined by the University at Buffalo). Under the auspices of GISP, this group first recovered three deep ice cores from around $400 \mathrm{~m}$, and in 1981 they successfully completed the Dye-3 deep ice core drilling to bedrock ( $2037 \mathrm{~m}$ ) using a Danish drill. The early deep ice cores were subjected to multiple and coordinated laboratory analyses; these data were promptly exchanged and cross-correlated among the scientific participants. The results of the investigations are widely published and have revealed substantial new paleoenvironmental data on conditions occurring at the Earth's surface over the time spans represented by their chronologies, which ranged in ages up to $115 \mathrm{kyrs}$ BP. Ice coring science has since grown, and in the last 10 - 15 years several new deep ice cores have reached depths exceeding $3000 \mathrm{~m}$, from both ice sheets, and have extended ice core records much further back in time. 


\section{References}

AGU. 1998. Greenland Summit Ice Cores, GRIP and GISP Projects. Articles by all participant authors, 1989-1993. American Geophysical Union, Washington, D.C. J ournal of Geophysical Research 1998: 26,315-26,886.

Ahlmann, H.W. 1933. Glaciology, scientific results of the Swedish-Norwegian Arctic Expedition, 1931. Geografiska Annaler 15: 2-3.

Ahlmann, H.W. 1935. The stratification of the snow and firn on Isachsen's Plateau. Scientific Results of the Norwegian and Swedish Spitzbergen Expedition, 1934.

Bader, H. 1953. Sorge's law of densification of snow on high polar glaciers. Research Paper 2. Wilmette, IL: USA Snow, Ice and Permafrost Research Establishment.

Bader, H. 1958. United States polar ice and snow studies in the International Geophysical Year. In Geophysics and the IGY, ed. H. Odishaw and S. Ruttenberg, Monograph 2, p. 177-181. Washington, DC: American Geophysical Union.

Bader, H. 1962. Scope, problems, and potential value of deep core drilling in ice sheets. Special Report 58. Hanover, NH: USA Cold Regions Research and Engineering Laboratory.

Bader, H. 1965. Theory of densification of dry, bubbly glacier ice. Research Report 141. Hanover, NH: USA Cold Regions Research and Engineering Laboratory.

Bader, H., R. Haefeli, E. Bucher, J . Neher, J . Eckel, and C. Chams. 1939. Snow and its metamorphism (Der Schnee und seine Metamorphose). Beitrage zur Geologie der Schweiz, Geotechnische Series, Hydrologie, Lieferung 3. Also Translation Report 14, J anuary 1954, Translated by J.C. Van Tienhoven. Wilmette, IL: USA Snow, Ice and Permafrost Research Establishment.

Bader H., R.W. Waterhouse, J .K. Landauer, B.L. Hansen, J .A. Bender, and T.R. Butkovich. 1955. Excavations and installations at SIPRE Test Site, Site 2, Greenland. Technical Report 20. Wilmette, IL: USA Snow, Ice and Permafrost Research Establishment.

Bender, J .A., and A.J . Gow. 1961. Deep drilling in Antarctica. Colloque sur la Glaciologie Antarctique. Publication No. 55, p. 132-141. International Association of Scientific Hydrology.

Benson, C.S. 1959. Physical investigations on the snow and firn of northwest Greenland 1952, 1953, and 1954. Research Report 26. Hanover, NH: USA Cold Regions Research and Engineering Laboratory.

Benson, C.S. 1962. Stratigraphic studies in the snow and firn of the Greenland ice sheet. Research Report 70. Hanover, NH: USA Cold Regions Research and Engineering Laboratory.

Berner, W., H.O. Oeschger, and B. Stauffer. 1980. Information on the $\mathrm{CO}_{2}$ cycle from ice core studies. Radiocarbon 22(2): 227-235. 
Cox, J .D. 2005. Climate crash: Abrupt climate change and what it means to our future. J oseph Henry Press.

Cragin, J.H., M.M. Herron, C.C. Langway, J r., and G. Klouda. 1974. Interhemispheric comparison of changes in the composition of atmospheric precipitation during the Late Cenozoic Era. Proceedings of the SCOR/ SCAR Polar Oceans Conference, Montreal, Canada, ed. M.J . Dunbar. p.617-631.

Cragin, J.H., M.M. Herron, C.C. Langway, J r. 1975. The chemistry of 700 years of precipitation at Dye 3, Greenland. Research Report 341. Hanover, NH: USA Cold Regions Research and Engineering Laboratory.

Crary, A.P., W.O. Field, and M.F. Meier. 1962. The United States glaciological researches during the International Geophysical Year. J ournal of Glaciology 4: 5-24.

Crozaz, G., and C.C. Langway, Jr. 1966. Dating Greenland firn-ice cores with Pb-210. Earth and Planetary Science Letters 1: 194-196.

Crozaz, G., C.C. Langway, J r., and E. Picciotto. 1966. Artificial radioactivity reference horizons in Greenland firn. Earth and Planetary Science Letters 1: 42-48. Also Research Report 208. Hanover, NH: USA Cold Regions Research and Engineering Laboratory.

Dansgaard, W. 2004. Frozen annals: Greenland ice sheet research. Odder, Denmark: Narayana Press.

Dansgaard, W., S.J . J ohnsen, J . Moller, and C.C. Langway, Jr. 1969. One thousand centuries of climate record from Camp Century on the Greenland Ice Sheet. Science 166: 377-381.

Dansgaard, W., S.J . J ohnsen, H.B. Clausen, and C.C. Langway, J r. 1970. Ice cores and paleoclimatology. In Radiocarbon variations and absolute chronology, ed. I. U. Olsen. Nobel Symposium XII. New York: J ohn Wiley.

Dansgaard, W., S.J . J ohnsen, H.B. Clausen, and C.C. Langway, J r. 1971. Climate record revealed by the Camp Century ice core. In Late Cenozoic Glacial Ages Symposium, ed. K.K. Turekian, 37-56. New Haven, CN: Yale University Press.

Dansgaard, W., H.B. Clausen, N. Gunderstrup, C.U. Hammer, S.J .J ohnsen, P.M. Krristindottir, and N. Reeh. 1982. A new Greenland deep ice core. Science 12731277.

Epstein, S., and R.P. Sharp. 1959. Oxygen-isotope studies. Transactions of the American Geophysical Union, Research Report no. 40, 81-84.

Epstein, S., R.P. Sharp, and A.J . Gow. 1970. Antarctic ice sheet stable isotope analyses of Byrd Station cores and inter-hemispheric climate implications. Science 168: 1570-1572.

Finkel, R.C., C.C. Langway, J r., and H.B. Clausen. 1986. Changes in precipitation chemistry at Dye 3, Greenland. J ournal of Geophysical Research 91(D9): 98499855. 
Fireman, E.L., and C.C. Langway, Jr. 1965. Search for aluminum-26 in dust from the Greenland Ice Sheet. Geochimica et Cosmochimica Acta 29: 21-27.

Gould, L.M. 1970. Polar research: A survey. Committee on Polar Research. Washington, DC: National Academy Press.

Gow, A.J . 1961. Drill-hole measurements and snow studies at Byrd Station, Antarctica. Technical Report 78. Hanover, NH: USA Cold Regions Research and Engineering Laboratory.

Gow, A.J . 1963. The inner structure of the Ross Ice Shelf at Little America V, Antarctica, as revealed by deep core drilling. 272-274, Pub. 61, General Assembly of Berkeley, International Association of Scientific Hydrology.

Gow, A.J . 1968. Deep core studies of the accumulation and densification of snow at Byrd Station and Little America V, Antarctica. Research Report 197. Hanover, NH: USA Cold Regions Research and Engineering Laboratory.

Gow, A.J . 1970. Preliminary results of studies of ice cores from the 2164m deep drill hole. Byrd Station, Antarctica. In International Symposium on Antarctic Glaciological Exploration (ISAGE), Sept. 1968, Hanover, NH, ed. A.J . Gow, C. Keeler, C.C. Langway, J r., and W.F. Weeks, 78-90. Publication 86. International Association of Scientific Hydrology.

Gudmansen, P. 1973. Radioglaciology soundings at proposed drill sites. Report D185. Lyngby, Denmark: Laboratory of Electromagnetic Theory, Technical University of Denmark.

Gudmansen, P. 1975. Layer echo's in polar ice sheets. J ournal of Glaciology 5 (73): 95101.

Gudmansen, P., E. Nilsson, M. Pallisgaard, N. Skou, and F. Sondergaard. 1975. New equipment for radio-echo sounding. Antarctic J ournal of the U.S. 10 (5): 234236.

Gundestrup, N.S., and S.J . J ohnsen. 1985. A battery powered, instrumented deep ice core drill for liquid filled holes. In Greenland ice core: Geophysics, geochemistry, and the environment, ed. C.C. Langway, J r., H. Oeschger, and W. Dansgaard. Geophysical Monograph 33: 19-22. Washington, D.C.: American Geophysical Union.

Gundestrup, N.S., S.J . J ohnsen, and N. Reeh. 1984. ISTUK: A deep ice core drill system. In Ice drilling technology, ed. G. Holdsworth. Special Report 84-34: 7-19. Hanover, NH: USA Cold Regions Research and Engineering Laboratory.

Hammer, C.U. 1977. Past volcanism revealed by Greenland Ice Sheet impurities. Nature 270: 482-486.

Hammer, C.U. 1980. Acidity of polar ice cores in relation to absolute dating, past volcanism, and radio echoes. J ournal of Glaciology 25: 359-372.

Hammer, C.U., H.B. Clausen, and W. Dansgaard. 1980. Greenland ice sheet evidence of post-glacial volcanism and its climatic impact. Nature 288: 230-235. 
Hammer, C.U., H. Clausen, W. Dansgaard, A. Neftal, P. Kristinsdoter, and E. J ohnson. 1985. Continuous impurity analysis along the Dye-3 core. In Greenland ice core: Geophysics, geochemistry, and the environment, ed. C.C. Langway, J r., H. Oeschger, and W. Dansgaard. Geophysical Monograph 33: 90-94. Washington, D.C.: American Geophysical Union.

Hammer, C.U., H.B. Clausen, and H. Tauber. 1986. Ice-core dating of the Pleistocene/ Holocene boundary applied to a calibration of the $14 \mathrm{C}$ time scale. Radiocarbon 28 (2A): 284-291.

Hansen, B.L. 1994. Deep core drilling in ice. In Proceedings of the Fourth International Workshop on Ice Drilling Technology, Tokyo, Japan, 5-8. National Institute of Polar Research.

Hansen, B.L., and C.C. Langway, Jr. 1966. Deep core drilling and core analysis at Camp Century, Greenland, 1961-1966. Antarctic J ournal of the U.S. 207-208.

Herron, M.M. 1982. Impurity sources of $\mathrm{F}^{-}, \mathrm{Cl}^{-}, \mathrm{NO}^{-3}$, and $\mathrm{SO}^{-2}$ in Greenland and Antarctic precipitation. J ournal of Geophysical Research 87: 3052-3060.

Herron, M.M., and C.C. Langway, J r. 1985. Chloride, nitrate, and sulfate in the Dye 3 and Camp Century, Greenland ice cores. In Greenland ice core: Geophysics, geochemistry, and the environment, ed. C.C. Langway, J r., H. Oeschger, and W. Dansgaard. Geophysical Monograph 33: 77-83. Washington, D.C.: American Geophysical Union.

Herron, M.M., S.L. Herron, and C.C. Langway, Jr. 1981. Climate signal of melt features in southern Greenland. Nature 293: 389-391.

Herron, S.L., and C.C. Langway, Jr. 1982. A comparison of ice fabrics and textures at Camp Century, and Byrd Station, Antarctica. Annals of Glaciology 3: 118-124.

Herron, S.L., and C.C. Langway, J r. 1987. Derivation of paleoelevations from total air content of two deep Greenland ice cores. In The Physical Basis of Ice Sheet Modeling, 19th IUUG General Assembly, Vancouver, B.C., Canada, Pub. 170: 283-290. International Association of Hydrologic Sciences.

Herron, S.L., C.C. Langway, J r., and K.A. Brugger. 1985. Ultrasonic and crystalline anisotropy in the ice core from Dye 3, Greenland. In Greenland ice core: Geophysics, geochemistry, and the environment, ed. C.C. Langway, Jr., H. Oeschger, and W. Dansgaard. Geophysical Monograph 33: 23-31. Washington, D.C.: American Geophysical Union.

Heuberger, J .C. 1954. Groenland, glaciology, Forages sur I'inlandis. 1: 63-84. Paris: Hermann and Cie.

Hodge, P.W., F.W. Wright, and C.C. Langway, Jr. 1964. Studies of particles for exterritorial origin, 3: Analyses of dust particles from polar ice deposits. J ournal of Geophysical Research 69: 2919-2931.

Hodge, P.W., F.W. Wright, and C.C. Langway, Jr. 1967. Studies of particles for extraterrestrial origin, 5: Composition of the interiors of spherules from Arctic and Antarctic ice deposits. J ournal of Geophysical Research 72: 1404-1406. 
Intergovernmental Panel on Climate Change. 2001. Climate change 2001-The scientific basis: contributions of Working Group I to the Third Assessment of the Intergovernmental Panel on Climate Change, ed. J.T. Houghton et al. New York: Cambridge University Press.

J ohnsen, S.J ., W. Dansgaard, H.B. Clausen, and C.C. Langway, Jr. 1970. Climate oscillations 1200-2000 A.D. Nature 227: 482-483.

J ohnsen, S.J ., W. Dansgaard, H.B. Clausen, and C.C. Langway, Jr. 1972. Oxygen isotope profiles through the Antarctic and Greenland ice sheets. Nature 235 (5339): 429434.

J unge, C. 1957. Personal Communication.

J unge, C. 1960. Sulfur in the atmosphere. J ournal of Geophysical Research 65: 227-237.

Koide, M., E.D. Goldberg, M.M. Herron, and C.C. Langway, J r. 1977. Transuranic depositional history in South Greenland firn layers. Nature 269: 137-139.

Korsmo, F.L. 2007a. The early Cold War. In Extremes: Oceanography's Adventures at the Poles, ed. K. Benson and H. Razwadowski. Chapter 6, 173-199. Watson Publishing.

Korsmo, F.L. 2007b. The genesis of the International Geophysical Year. Physics Today 60(7): 38-43.

Lange, G.R. 1973. Deep rotary core drilling in ice. Technical Report 94. Hanover, NH: USA Cold Regions Research and Engineering Laboratory.

Langway, Jr., C.C., 1958a. A 400 meter deep ice core in Greenland, Preliminary Report. J ournal of Glaciology 3: 216-217.

Langway, Jr., C.C. 1958b. Bubble pressures in Greenland glacier ice. In Symposium of Chamonix, France, Publication 47: 336-349. International Association of Scientific Hydrology.

Langway, J r., C.C. 1958c. Ice fabrics and the universal stage. Technical Report 62. Wilmette, IL: U.S. Army Snow, Ice and Permafrost Research Establishment.

Langway, J r., C.C. 1962. Some physical and chemical investigations of a 411m deep Greenland ice core and their relationship to accumulation. In Colloquium of Obergurgl, Austria, Publication 58: 101-118. International Association of Scientific Hydrology.

Langway, J r., C.C. 1963. Sampling for extraterrestrial dust on the Greenland ice sheet. In General Assembly of Berkeley, CA, USA, Publication 61: 189-198. International Association of Scientific Hydrology.

Langway, J r., C.C. 1967. Stratigraphic analysis of a deep ice core from Greenland. Research Report 77. Hanover, NH: USA Cold Regions Research and Engineering Laboratory. Also Special Paper 125, 1970. Boulder, CO: Geological Society of America. 
Langway, J r., C.C. 1968. Deep ice core study program: Greenland. Antarctic J ournal of the U.S. 3 (5): 184-185.

Langway, Jr., C.C. 1976. Greenland Ice Sheet Program (GISP) Science Plan. Second Edition. Washington, D.C.: Division of Polar Programs, U.S. National Science Foundation, National Science Board.

Langway, J r., C.C. and B.L. Hansen. 1970. Drilling through the ice cap: Probing climate for a thousand centuries. Bulletin of the Atomic Scientist 26 (10): 62-66.

Langway, Jr., C.C., and E.L. Fireman. 1966. Studies on collections of large masses of Greenland dust. Technical Note. Hanover, NH: USA Cold Regions Research and Engineering Laboratory.

Langway, J r., C.C., and U.B. Marvin. 1964. Comparison between snow-imbedded and industrial black spherules. Research Report 154. Hanover, NH: USA Cold Regions Research and Engineering Laboratory. Also in Conference on Cosmic Dust, Nov. 1963, 119: 205-223. New York Academy of Science.

Langway, J r., C.C., H.O. Oeschger, B. Alder, and A. Renaud. 1965. Sampling polar ice for radiocarbon dating. Nature 206 (4983): 500-501.

Langway, J r., C.C., B.L. Hansen, B.L. Oeschger, and B. Stauffer. 1969. Carbon dating ice at Byrd Station Antarctica. Antarctic J ournal of the U.S. 4 (4): 123-124.

Langway, J r., C.C., H.O. Oeschger, and W. Dansgaard, ed. 1985. Greenland ice cores: Geophysics, geochemistry, and the environment. Geophysical Monograph 33. Washington, D.C.: American Geophysical Union.

Langway, C.C., J r., K. Osada, H.B. Clausen, C.U. Hammer, H. Shoji, and A. Mitani. 1994. New chemical stratigraphy over the last millennium for Byrd Station, Antarctica. Tellus 46B: 40-51.

Langway, C.C., J r., K. Osada, H.B. Clausen, C.U. Hammer, and H. Shoji. 1995. A 10century comparison of prominent bipolar volcanic events in ice cores. J ournal of Geophysical Research 100: 16,241- 16,247.

Marshall, E.W. 1959. Stratigraphic use of particulates in polar ice caps. Geological Society of America Bulletin 70: 1643.

Marshall, E.W., 1962. The stratigraphic distribution of particulate matter in the firn at Byrd Station, Antarctica. American Geophysical Union, Geophysical Monograph 7, p 185-196.

McCorkell, R.H., E.L. Fireman, C.C. Langway, Jr. 1967. Aluuminum-26 and beryllium-10 in Greenland ice. Science 158: 1690-1692.

McCorkell, R.H.,W.H. Pinson, E.L. Fireman, and C.C. Langway, J r. 1968. A search for cosmic dust in a large collection of particulate and dissolved material from polar ice. In International Symposium on Antarctic Glaciological Exploration (ISAGE). Publication 86: 25-30. International Association of Scientific Hydrology. 
Mellor, M. 1964. Glaciological techniques. In Snow and Ice on the Earth's Surface. Cold Regions Science and Engineering Monograph IIC1: 147- 161. Hanover, NH: U.S. Army Cold Regions Research and Engineering Laboratory.

Mellor, M., and P.V. Sellmann. 1976. General considerations for drill system design. In Ice-core Drilling, ed. J . Splettstoesser, 77-111. Lincoln, NE: University of Nebraska Press.

Miller, M.M. 1954. J uneau Icefield Research Project, Alaska, 1950. J IRP Report 7. American Geographical Society.

Mitchell, J r., J .M., and W.W. Kellogg. 1984. Polar Research Board, Committee on the Role of the Polar Regions. In Climatic change, the polar regions and climatic change, and Appendix B, Polar regions as window to the past: Glacier ice records, 41-55. Washington, D.C.: National Academy Press.

Mock, S.J . 1965. Glaciological studies in the vicinity of Camp Century, Greenland, USA. Research Report 157. Hanover, NH: USA Cold Regions Research and Engineering Laboratory.

Morrison, J.T., M.T. Brockwell, F. Fourel, and A. Phillips. 2001. On-line high-precision stable hydrogen isotopic analysis on nanolitre water samples. Analytical Chemistry 73 (15): 3570-3575.

Oeschger, H. 1985. The contribution of ice core studies to the understanding of environmental processes. In Greenland ice core: Geophysics, geochemistry, and the environment, ed. C.C. Langway, Jr., H. Oeschger, and W. Dansgaard. Geophysical Monograph 33: 9-17. Washington, D.C.: American Geophysical Union.

Oeschger, H., and C.C. Langway, Jr., ed. 1989. The environmental record in glaciers and ice sheets. Dahlem Workshop Report No. 8, March 1988, Berlin, Germany.J ohn Wiley and Sons.

Oeschger, H., and U. Sigenthaler. 1988. How has the atmospheric concentration of CO2 changed? In Report of the Dahlem Workshop on the Changing Atmosphere, ed. F.S. Rowlad and I.S. Isaksen. 5-23. Wiley and Sons.

Oeschger, H., B. Alder, and C.C. Langway, Jr. 1966. Radiocarbon dating of ice. Earth and Planetary Science Letters 1(2): 49-54.

Oeschger, H., B. Alder, and C.C. Langway, J r. 1967. An in situ gas extraction system to radiocarbon date glacier ice. Research Report 236. Hanover, NH: USA Cold Regions Research and Engineering Laboratory. Also J ournal of Glaciology 6 (48): 939-942.

Osada, K. 1996. Water soluble constituents in polar ice cores: Temporal and spatial distribution of sulfate in polar ice. PhD Thesis, Nagoya University, J apan.

Osada, K., and C.C. Langway, J r. 1993. Background levels of formate and other ions in ice cores from inland Greenland. Geophysical Research Letters 20: 2647- 2650. 
Patenaude, R.W., E.W. Marshall, and A.J . Gow. 1959. Deep core drilling in ice, Byrd Station, Antarctica. Technical Report 60. Wilmette, IL: USA Snow, Ice and Permafrost Research Establishment.

Ragle, R.H. 1958. Polar glaciology study course. Special Report 26. Wilmette, IL: U.S. Army Snow, Ice and Permafrost Research Establishment.

Ragle, R.H., B.L. Hansen, A.J . Gow, and R.W. Patenaude. 1960. Deep core drilling in the Ross Ice Shelf. Little America V, Antarctica, Parts I and II. Technical Report 70: p 10. Wilmette, IL: U.S. Army Snow, Ice and Permafrost Research Establishment.

Rand, J . 1980. GISP, Phase 1: Casing operation. Special Report 80-24. Hanover, NH: USA Cold Regions Research and Engineering Laboratory.

Rand, J ., and M. Mellor. 1985. Ice-coring augers for shallow depth sampling. Research Report 85-21. Hanover, NH: USA Cold Regions Research and Engineering Laboratory.

Rodriquez, R. 1963. Development of glacial subsurface water supply and sewage systems. Technical Report 1737-TR. Fort Belvoir, VA: U.S. Army Engineer Research and Development Laboratories.

Schwander, J., and B. Stauffer. 1984. Age difference between polar ice and the air trapped in its bubbles. Nature 311: 45-47.

Schwarzbach, M. 1986. Alfred Wegener: Father of continental drift. Scientific Revolutionaries: Biographical Series. Madison, WI: Science Tech.

Schytt, V. 1958. Norwegian-British-Swedish Antarctic Expedition 1949-1952. Scientific Results 4. Glaciology II. Oslo, Norway: Norsk Polarinstitut.

Shoji, H., and C.C. Langway, J r. 1982. Air hydrate inclusions in fresh ice core. Nature 298: 548-550.

Shoji, H., and C.C. Langway, Jr. 1987. Microscopic observations of the air hydrate-bubble transformation process in glacier ice. J ournal Physique Cl: 551-558.

Shoji, H., and C.C. Langway, Jr. 1989. Physical property reference horizons. In The environmental record in glaciers and ice sheets, Dahlem Workshop, March 1988, Berlin, Germany. Report No. 8: 161-175. New York: J ohn Wiley and Sons.

Sorge, E. 1933. Scientific results of the Wegener Expedition to Greenland. Geographical J ournal 81: 333- 334.

Sorge, E. 1935. Glaziologische Untersuchungen in Eismitte (Glaciological research at Eismitte). In Wissenschaftliche Ergebnisse der Deutschen Groenland Expedition Alfred Wegener 1929 und 1930-31, 3: 270. Leipzig, Germany: F. A. Brokaus.

Stauffer, B. 1985. Increase of atmospheric methane recorded in Antarctic ice core. Science 229: 1386-1388.

Stauffer, B., E. Loochbronner, H. Oeschger, and J . Schwander. 1988. Methane concentrations in the glacial atmosphere was only half that of the preindustrial Holocene. Nature 332: 812-814. 
Sverdrup, H.U. 1935. The temperature of the firn on Isachsen's Plateau and general conclusions regarding the temperature of the glaciers on West-Spitzbergen. In Scientific results of the Norwegian-Swedish Spitzbergen Expedition, 1934. Geografisker Annaler 17: 78- 80.

Swithinbank, C. 1957. Norwegian-British-Swedish Antarctic Expedition 1949-1952. Scientific Results 3. Glaciology I. Oslo, Norway: Norsk Polarinstitut.

Ueda, H.T., and D.E. Garfield. 1968. Drilling through the Greenland Ice Sheet. Special Report 126. Hanover, NH: USA Cold Regions Research and Engineering Laboratory.

Ueda, H.T., and D.E. Garfield. 1969a. The USA CRREL drill for thermal coring in ice. J ournal of Glaciology 8 (53): 311-314.

Ueda, H.T., and D.E. Garfield. 1969b. Core drilling through the Antarctic ice sheet. Technical Report 231. Hanover, NH: USA Cold Regions Research and Engineering Laboratory.

Vinther, B.M., H.B. Clausen, S.J . J ohnsen, S.O. Rasmussen, K.K. Andersen, S.L. Buchardt, D. Dahl-J ensen, I.K. Seierstad, M.-L. Siggaard-Andersen, J .P. Stephenson, A. Swenson, J . Olseb, and J . Heinemeir. 2006. A synchronized dating of three Greenland ice cores throughout the Holocene. J ournal of Geophysical Research 111D13102.

Weertman, J . 1978. Committee report for NSF's Division of Polar Programs. Considerations for the selection of the GISP deep ice core drilling site. Washington, D.C.

Weertman, J . 1986. Recommendations for a U.S. ice coring program. Polar Research Board, ad hoc panel on Polar Ice Coring. Washington, D.C.: National Academy Press.

Wright, F.W., P.W. Hodge, and C.C. Langway, Jr. 1963. Studies of particles for extraterrestrial origin, 1: Chemical analyses of 118 particles. J ournal of Geophysical Research 69: 2919-2931. 


\section{Appendix A: Recovered Deep and Very Deep Ice Cores}

\begin{tabular}{|c|c|c|c|c|}
\hline Locations & Years & Type of drill & $\begin{array}{l}\text { Core diameter } \\
(\mathrm{cm})\end{array}$ & $\begin{array}{l}\text { Depth } \\
(\mathrm{m})\end{array}$ \\
\hline \multicolumn{5}{|l|}{ IGY Locations } \\
\hline Site 2, Greenland & 1956 & Rotary mechanical (U.S.) & 10 & 305 \\
\hline Site 2, Greenland & 1957 & Rotary mechanical (U.S.) & 10 & 411 \\
\hline Byrd Station, Antarctica & $1957-58$ & Rotary mechanical (U.S.) & 10 & 307 \\
\hline Little America, V Antarctica & $1958-59$ & Rotary mechanical (U.S.) & 10 & 264 \\
\hline Camp Century, Greenland & $1961-1966$ & Thermal (U.S) & 12.4 & $0-535$ \\
\hline Camp Century, Greenland & 1961-1966 & Electromechanical (U.S.) & 9.1 & $535-1387$ \\
\hline Byrd Station, Antarctica & $1966-1968$ & Electromechanical (U.S.) & 10.2 & 2164 \\
\hline \multicolumn{5}{|l|}{ GISP Locations } \\
\hline Dye-3, Greenland & 1971 & Thermal (U.S.) & 12.7 & 372 \\
\hline Milcent, Greenland & 1973 & Thermal (U.S.) & 12.7 & 398 \\
\hline Crete, Greenland & 1974 & Thermal (U.S.) & 12.7 & 405 \\
\hline Dye-3, Greenland & $1979-1981$ & Electromechanical (GISP, Denmark) & 10.2 & 2037 \\
\hline \multicolumn{5}{|l|}{ Recent International Locations } \\
\hline GRIP, Greenland & 1989-1992 & Electromechanical (Denmark) & 10.2 & $0-3029$ \\
\hline GISP-2, Greenland & $1989-1993$ & Electromechanical (U.S.) & 13.2 & $0-3057$ \\
\hline Vostock, Antarctica* & $1990-1993$ & Thermal (Soviet Union) & $11.0-11.2$ & $0-2755$ \\
\hline Vostock, Antarctica* & $1994-1998$ & Electromechanical (Russia) & 10.7 & $2755-3623$ \\
\hline Vostock, Antarctica* & $2005-2007$ & Electromechanical (Russia) & 10.7 & $3623-3658$ \\
\hline Dome Fuji, Antarctica I $^{\dagger}$ & $1994-1997$ & Electromechanical (Japan) & 9.4 & $0-2503$ \\
\hline 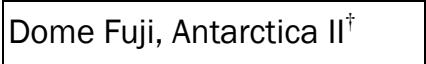 & 2003-2007 & Electromechanical (Japan) & 9.4 & $0-3035$ \\
\hline NGRIP, Greenland** & $1996-1997$ & Electromechanical (Denmark) & 10.2 & $0-1300$ \\
\hline NGRIP, Greenland** & 1999 & Electromechanical (Denmark) & 10.2 & $1300-1750$ \\
\hline NGRIP, Greenland** & 2000 & Electromechanical (Denmark) & 10.2 & $1750-2931$ \\
\hline NGRIP, Greenland** & 2003 & Electromechanical (Denmark) & 10.2 & $2931-3085$ \\
\hline NGRIP, Greenland** & 2004 & Electromechanical (Denmark) & 10.2 & $3085-3090$ \\
\hline Dome C, Antarctica $^{\dagger}$ & 1999-2005 & $\begin{array}{l}\text { Electromechanical (EPICA, France } \\
\text { and Italy) }\end{array}$ & 9.8 & $0-3270$ \\
\hline Kohnen Station, Antarctica $^{\dagger}$ & 2001-2006 & Electromechanical (EPICA, Germany) & 9.8 & $0-2774$ \\
\hline
\end{tabular}

*Data provided by Pavel G. Talalay, St. Petersberg State Mining Institute, Russia.

${ }^{\dagger}$ Data provided by Nobuhiko Azuma, Nagaoka University of Technology, Japan.

**Data provided by Henrik Clausen, University of Copenhagen, Denmark. 


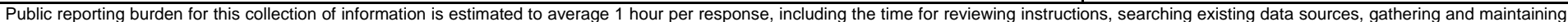

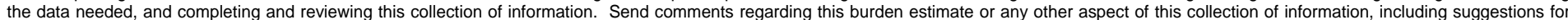

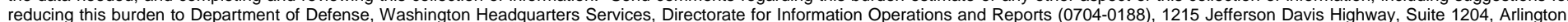

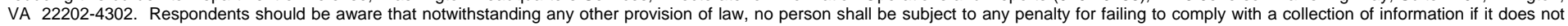
display a currently valid OMB control number. PLEASE DO NOT RETURN YOUR FORM TO THE ABOVE ADDRESS.
1. REPORT DATE (DD-MM-YYYY) 2. REPORT TYPE January 2008 Technical Report 4. TITLE AND SUBTITLE
3. DATES COVERED (From - To)

5a. CONTRACT NUMBER

5b. GRANT NUMBER

5c. PROGRAM ELEMENT NUMBER

5d. PROJECT NUMBER

5e. TASK NUMBER

5f. WORK UNIT NUMBER

8. PERFORMING ORGANIZATION REPORT NUMBER

ERDC/CRREL TR-08-1

U.S. Army Engineer Research and Development Center

Cold Regions Research and Engineering Laboratory

72 Lyme Road

Hanover, NH 03755-1290

9. SPONSORING I MONITORING AGENCY NAME(S) AND ADDRESS(ES)
10. SPONSOR/MONITOR'S ACRONYM(S)

11. SPONSOR/MONITOR'S REPORT NUMBER(S)

\section{DISTRIBUTION I AVAILABILITY STATEMENT}

Approved for public release; distribution is unlimited.

Available from NTIS, Springfield, Virginia 22161.

\section{SUPPLEMENTARY NOTES}

\section{ABSTRACT}

The scientific knowledge of the Greenland and Antarctic ice sheets, and the subsequently derived Earth history, has been greatly increased during the past 50 years. Much of the new information was obtained from various studies made on a relatively small number of deep (300-400 m) and several very deep (some over $3000 \mathrm{~m}$ ) ice cores, recovered from the inland regions of both ice sheets by different national and international research teams. The beginning, development, and progress of deep polar ice core drillings and core studies is reviewed from the incipient pit study made by Ernst Sorge in 1930, through the trying efforts of three international core drilling projects mounted around 1950. The paper continues with a broad overview of the early role and achievements made by two related U.S. Army Corps of Engineers research laboratories: the Snow, Ice and Permafrost Research Establishment (SIPRE), and the Cold Regions Research and Engineering Laboratory (CRREL), from the early 1950s to the late 1980s. International partnerships of CRREL with the University of Copenhagen, Denmark, and the University of Bern, Switzerland, starting in 1962, established the foundation of polar ice core science.

\section{SUBJECT TERMS}

Antarctica

Climate change

16. SECURITY CLASSIFICATION OF:

a. REPORT

U
Glaciology

Greenland

Ice cores

Ice cores

c. THIS PAGE

U

\begin{tabular}{|c|c|} 
17. LIMITATION & 18. NUMBER \\
OF ABSTRACT & OF PAGES \\
\cline { 3 - 3 }$U$ & 57 \\
\hline
\end{tabular}

Paleoclimatology

19a. NAME OF RESPONSIBLE PERSON

19b. TELEPHONE NUMBER (include area code) 